\title{
33. MAJOR-OXIDE STRATIGRAPHY OF GLASS SHARDS IN VOLCANIC ASH LAYERS OF THE IZU-BONIN ARC-BACKARC SITES (SITES 788/789 AND 790/791) ${ }^{1}$
}

\author{
K. S. Rodolfo, ${ }^{2}$ R. U. Solidum, ${ }^{2}$ A. Nishimura, ${ }^{3}$ Y. Matsuo,${ }^{4}$ and K. Fujioka ${ }^{5}$
}

\begin{abstract}
To examine the processes and histories of arc volcanism and of volcanism associated with backarc rifting, 130 samples containing igneous glass shards were taken from the Pliocene-Quaternary succession on the rift flank (Site 788) and the Quaternary fill in the basin fill of the Sumisu Rift (Sites 790 and 791). These samples were subsequently analyzed at the University of Illinois at Chicago and Shizuoka University. The oxides determined by electron probe do not account for the total weight of the material; differences between summed oxides and $100 \%$ arise from the water contents, probably augmented by minor losses that result from alkali vaporization during analysis. Weight losses in colorless glasses are up to $9 \%$; those in brown glasses (dacites to basalts) are no more than $4.5 \%$; shards from the rift-flank (possibly caused by prolonged proximity to the seafloor) generally have higher values than those from the rift-basin fill. How much of the lost water is magmatic, and how much is hydrated is uncertain; however, although the shards absorb potassium, calcium, and magnesium during hydration in the deep sea, they do so only to a minor extent that does not significantly alter their major element compositions. Therefore, the electron-probe results are useful in evaluating the magmatism recorded by the shards.

Pre- and syn-rift Izu-Bonin volcanism were overwhelmingly dominated by rhyolite explosions, demonstrating that island arcs may experience significant silicic volcanism in addition to the extensive basaltic and basaltic andesitic activity, documented in many arcs since the 1970 s, that occurs in conjunction with the andesitic volcanism formerly thought to be dominant. Andesitic eruptions also occurred before rifting, but the andesitic component in our samples is minor. All the pre- and syn-rift rhyolites and andesites belong to the low-alkali island-arc tholeiitic suite, and contrast markedly with the alkalic products of Holocene volcanism on the northernmost Mariana Arc that have been attributed to nascent rifting.

The Quaternary dacites and andesites atop the rift flank and in the rift-basin fill are more potassic than those of Pliocene age, as a result of assimilation from the upper arc crust, or from variations in degrees of partial melting of the source magmas, or from metasomatic fluids. All the glass layers from the rift-flank samples belong to low- $\mathrm{K}$ arc-tholeiitic suites. Half of those in the Pliocene succession are exclusively rhyolitic; the others contain minor admixtures of dacite and andesite, or andesite and either basaltic andesite or basalt. In contrast, the Quaternary (syn-rift) volcaniclastics atop the rift-flank lack basalt and basaltic andesite shards. These youngest sediments of the rift flank show close compositional affinities with five thick layers of coarse, rhyolitic pumice deposits in the basin fill, the two oldest more silicic than the younger ones. The coarse layers, and most thin ash layers that occur in hemipelagites below and intercalated between them, are low-K rhyolites and therefore probably came from sources in the arc. However, several thin rhyolitic ash beds in the hemipelagites are abnormally enriched in potassium and must have been provided by more distal sources, most likely to the west in Japan.

Remarkably, the Pliocene-Pleistocene geochemistry of the volcanic front does not appear to have been influenced by the syn-rift basaltic volcanism only a few kilometers away. Rare, thin layers of basaltic ash near the bases of the rift-basin successions are not derived from the arc. They deviate strongly from trends that the arc-derived glasses display on oxide-oxide plots, and show close affinities to the basalts erupted all over the Sumisu Rift during rifting. These basalts, and the basaltic ashes in the basal rift-basin fill, are compositionally similar to those erupted from mature backarc basins elsewhere.
\end{abstract}

\section{INTRODUCTION}

A primary objective of Ocean Drilling Program (ODP) Leg 126 was to explicate the processes and history of arc volcanism, and especially of volcanism associated with backarc rifting, by recovering and examining sediments and rocks that fill the rift basins, as well as adjacent pre-rift rocks. Over the past two decades, extensive analyses of materials sampled by the Deep Sea Drilling Project (DSDP) have shown that volcanic glasses are fairly faithful indicators of magma compositions. In the deep-sea environment, although glasses are readily hydrated and absorb potassium, calcium, and magnesium, they do so only to a minor extent that does not significantly alter their major element compositions, as seen by Scheidegger et al. (1978) in

'Taylor, B., Fujioka, K., et al., 1992. Proc. ODP, Sci. Results, 126: College Station, TX (Ocean Drilling Program).

${ }^{2}$ Department of Geological Sciences, M/C 186, University of Illinois at Chicago, P. O. Box 4348, Chicago, IL 60680, U.S.A.

${ }^{3}$ Marine Geology Department, Geological Survey of Japan, 1-1-3 Higashi, Ibaraki 305, Japan.

${ }_{5}^{4}$ Institute of Geosciences, Shizuoka University, 836 Oya, Shizuoka, 422, Japan.

5 Ocean Research Institute, University of Tokyo, 1-15-1 Minamidai, Nakano, Tokyo 164, Japan (present address: Japan Marine Science and Technology Center, 2-14 Natsushima, Yokosuka, Kanagowa 238, Japan). the similarity of atomic-absorption data (which provide bulk analyses) and electron probe data (which analyze shard interiors) for glasses sampled by DSDP Leg 19 in the northwest Pacific. Were alteration significant, it would progress from shard margins to their interiors, thereby resulting in significant differences in the bulk and interior compositions.

Numerous volcanic ash layers several millimeters to several centimeters thick were recovered from Sites 790 and 791 in the basin fill of the Sumisu Rift, and others were sampled from sparsely recovered sedimentary cores taken at Site 788 on the eastern ridge-flank uplift. These thin layers of fine tephra were sampled by investigators from both the United States and Japan, and glass shards from the samples were analyzed for major oxide chemistry by electron microprobe at the Department of Geological Sciences of the University of Illinois at Chicago (UICDoGS) and at the Institute of Geosciences of Shizuoka University (IGSU). In addition, fine fractions from five thick layers of pumice in the basin fill that are the subject of other reports (Nishimura et al., 1991; Nishimura et al., this volume) were also analyzed, although less systematically. We present and discuss the results of these analyses in this report.

Figures 1,2, and 3 show how the backarc sites are spatially and stratigraphically related. Sites 788 and 789 are situated on the eastern foot wall of the rift-flank uplift $1100 \mathrm{~m}$ below sea level (mbsl). 


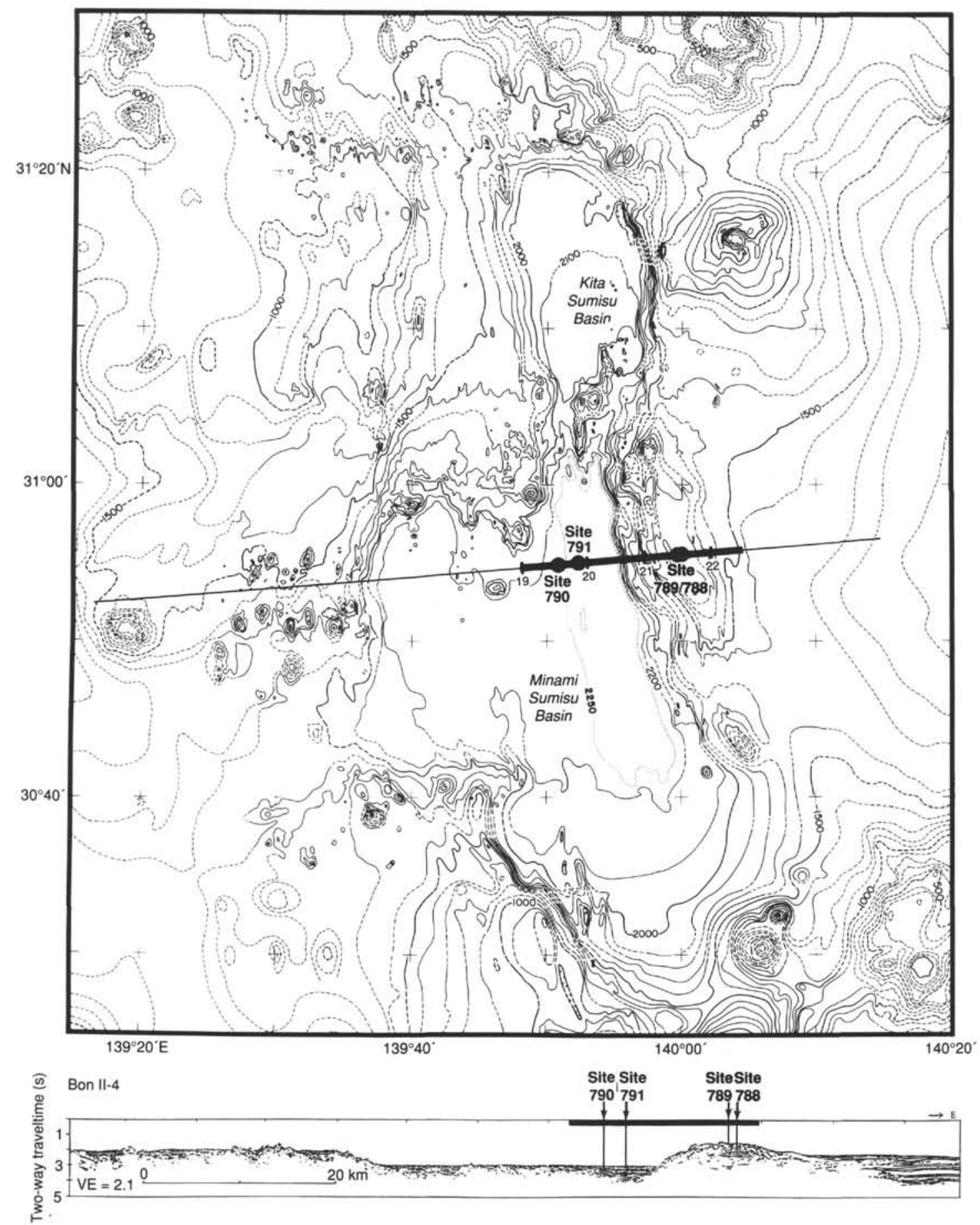

Figure 1. Bathymetry (100-m contour interval) of the Sumisu Rift, showing the Kita-Sumisu and Minami-Sumisu basins, and the backarc sites. The segment of MCS Line BON II-4 that crossed all of the backarc sites is shown on the chart, and a line drawing of the seismic reflection profile along the line segment is shown at the bottom of the figure. The solid bar above the profile indicates the segment of Line BON II- 4 that is depicted in Figure 2 (from Taylor, Fujioka, et al., 1990, p. 416).

Sites 790 and 791 were drilled in water about twice as deep ( 2223 and $2271 \mathrm{mbsl}$, respectively) into the flat floor of the rift basin. Site 790 is located $15 \mathrm{~km}$ west of Site 788, at the western side of the eastern half-graben of the rift, on the margin of an intrabasinal high. Site 791 was drilled $2.4 \mathrm{~km}$ east of Site 790 .

For all practical purposes, the sedimentary record of the ridgeflank uplift was recovered at Site 788 alone (Holes 788C and 788D), because Site 789, on the uplift $3 \mathrm{~km}$ west of Site 788, was not drilled successfully. Igneous rock was not reached by the drill at Site 788; it lies so far below the drilled interval that it is not even indicated on seismic reflection records. The sedimentary succession of Site 788 consists predominantly of coarse, rhyolitic pumice gravel and its lithified equivalents, although the presence of carbonate-rich intervals in its lower portion provided the basis for dividing it into two units. Recovery was poor from Unit II, the entirely lithified, oldest sampled rocks of the backarc region (4.77-4.2 Ma; Taylor, Fujioka, et al., 1990, pp. 97-124), and its glass shards were too altered for us to analyze. Therefore, we present detailed descriptions and chemical 


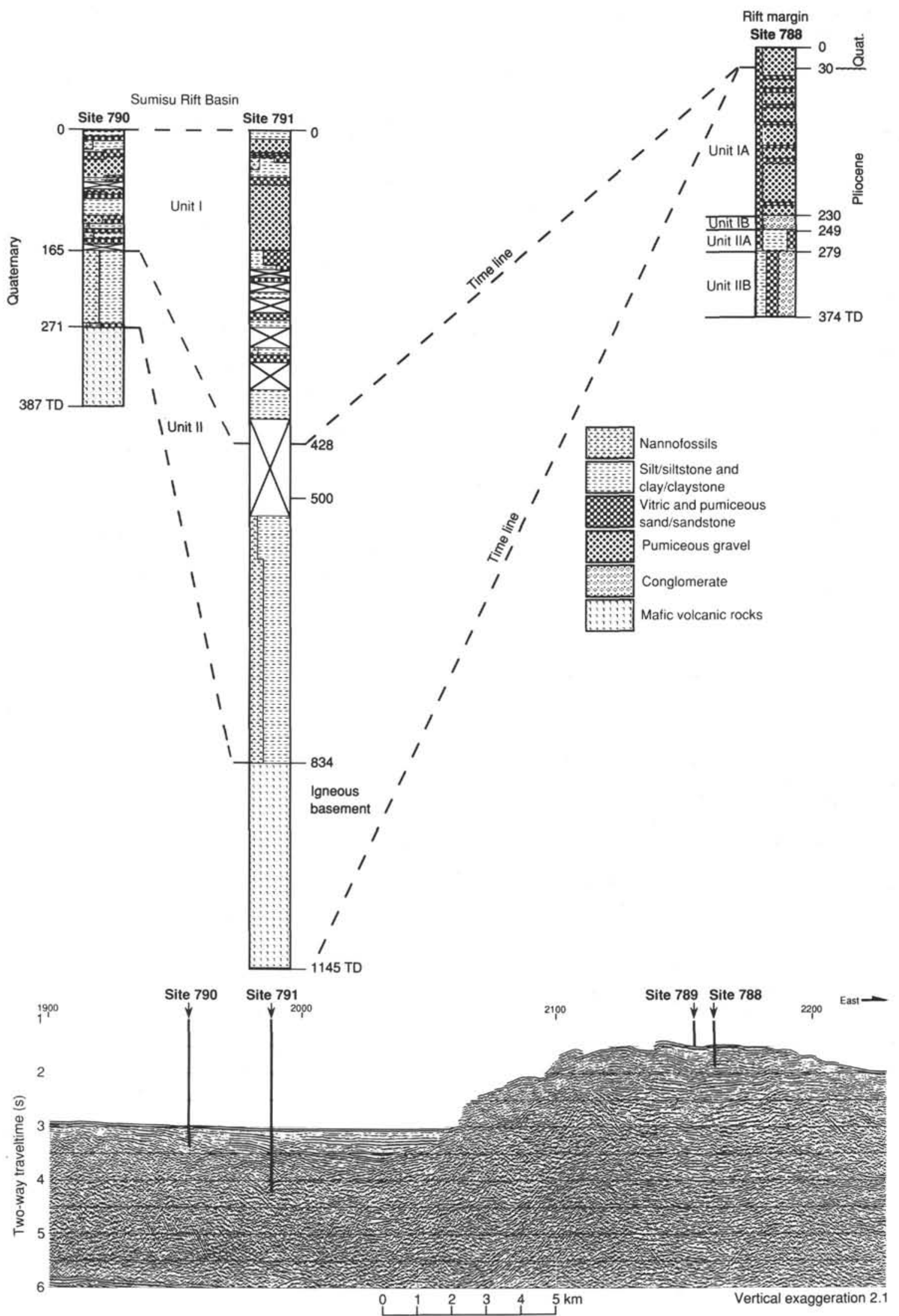

Figure 2. Stratigraphic correlation diagram for the backarc sites. The seismic profile is the segment of latitudinal MCS profile BON II-4 across the eastern footwall uplift and eastern half graben of the Sumisu Rift (from Taylor, Fujioka, et al., 1990, p. 417). 


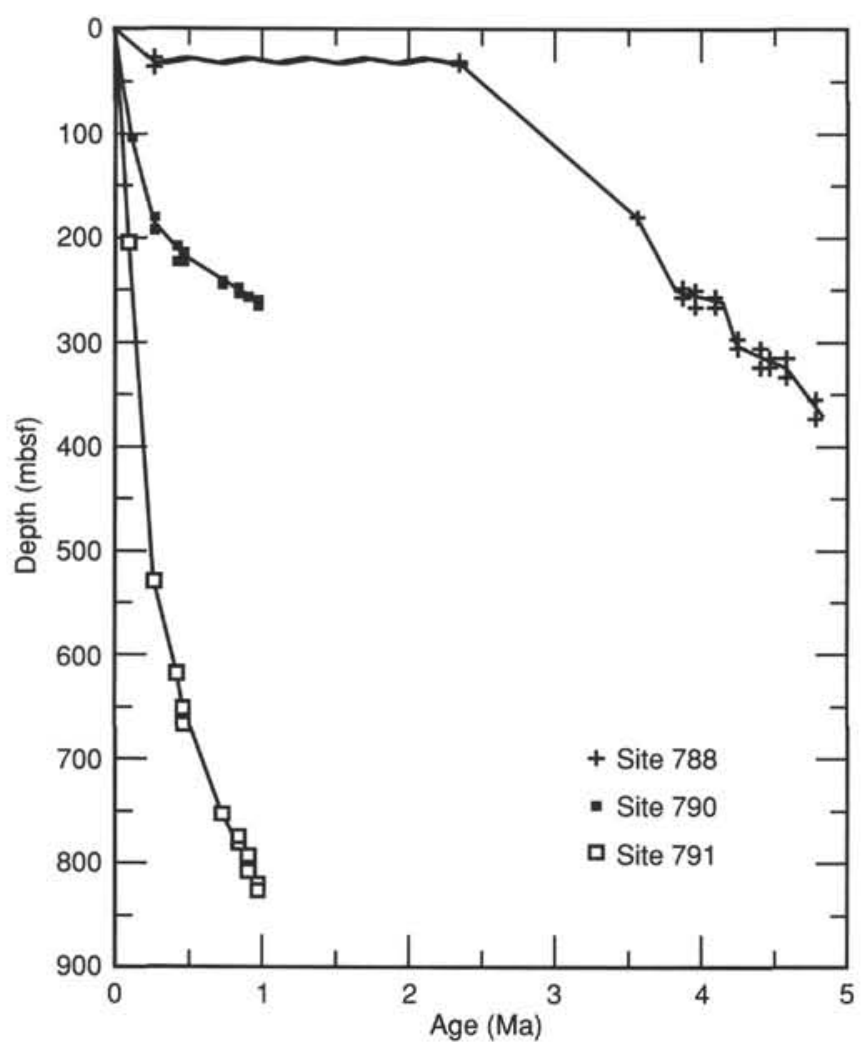

Figure 3. Age-depth plots for the backarc sites. The wavy line on the Site 788 curve is an unconformity (from Taylor, Fujioka, et al., 1990, p. 418).

analyses only from Unit I, the younger flank-uplift sediments that were reasonably well recovered and that contained fresh pumice clasts and glass shards. A total of 12 ash layers sampled from Unit I in Hole $788 \mathrm{C}$ were analyzed, all at UICDoGS.

The sedimentary succession that constitutes the rift-basin fill has been reconstructed from five holes: three at Site 790 (Holes 790A, 790B, and 790C) and two at Site 791 (Holes 791A and 791B), at which recovery and stratigraphic overlap were, for the most part, reasonably good. Overlying Pleistocene basaltic igneous rock, the basal sedimentary accumulations at both rift-basin sites are roughly equivalent in age (1.1 Ma in age at Site 790 and about $1 \mathrm{Ma}$ at Site 791), and the sediments belong to the same two units: lower Unit II of hemipelagites with rare, thin, isolated ash layers, and upper Unit I, dominated by coarse, pumiceous debris. A total of 1257 individual glass shards from 118 tephra layers from the successions at Sites 790 and 791 were analyzed (Table 1). Of these, 7 analyses from Site 790 and 12 from Site 791 yielded isolated, aberrant values that were discarded.

There is very little stratigraphic overlap between the sediments and sedimentary rocks of the rift-flank uplift and the rift-basin fill. Igneous rock (basalt) was cored only at the basin-floor sites, where it is also Quaternary (1.0-1.1 Ma) in age. Most of the pumiceous sedimentary succession drilled on the uplift is Pliocene and entirely predates the rifting. Only the uppermost $30 \mathrm{~m}$ of sediment that caps the uplift postdates the Quaternary rifting (like the total sedimentary accumulation of the rift-basin floor), being separated from the underlying Pliocene pumiceous gravels by a hiatus that is visibly indiscernible but was indicated by biostratigraphic evidence (Taylor, Fujioka, et al., 1990, pp. 97-124). This hiatus is significant because it dates the time of rifting. Below the hiatus, the age of these pumiceous gravel beds on the uplift is between 2.85 and $2.35 \mathrm{Ma}$, depending upon the actual sedimentation rate, which could be as high as $230 \mathrm{~m} / \mathrm{m}$.y. and as low as $145 \mathrm{~m} / \mathrm{m} . \mathrm{y}$. (Fig. 3). The gravels immediately above the hiatus were biostratigraphically dated at $0.275 \mathrm{Ma}$, the minimum age for rifting. Rifting could have occurred as early as $2.85 \mathrm{Ma}$; however, several lines of petrologic evidence indicate a significantly later time. Unit II and lowermost Unit I are lithified, and pumice grains and foraminifers in Unit II exhibit ductile and/or brittle deformation, indicating compaction by an overlying sedimentary column that must have been significantly thicker than it is at present (Nishimura et al., 1991). The missing overburden, its uppermost portion indeterminately younger than $2.85 \mathrm{Ma}$, was likely truncated by mass movements associated with rifting (Nishimura et al., 1991, and this volume). Thus, rifting, estimated by Taylor (this volume) to have occurred at $2 \mathrm{Ma}$, may well have occurred even closer to the 1.0-1.1 Ma age of the syn-rift basalts immediately below the sedimentary fill of the rift basin.

The minimum accumulation rate for the Quaternary sediments is $115 \mathrm{~m} / \mathrm{m}$.y. The actual rate is not known and depends on the age of the sediments at the very surface. Discolored, oxidized pumice clasts, and a pronounced depletion in fines, suggest that the surface deposits have resided for some time at the seafloor where they were subjected to oxidation and winnowing.

\section{Pliocene-Quaternary Rift-flank Succession (Site 788)}

Unit I of Site 788 overlies Unit II at 249 mbsf. Composed principally of poorly sorted ash and pumiceous tephra of sand to pebble sizes, it has a basal age of $3.66 \mathrm{Ma}$. The basal $19 \mathrm{~m}$ (Subunit IB) is transitionally lithified. Coarsening-upward trends subdivide the unit into four intervals 30-50 m thick (Nishimura et al., 1991, and this volume), the uppermost being the 30-m-thick Quaternary interval that was lithologically indistinguishable from the underlying Pliocene beds. Although the pumiceous Unit I sediments are generally depleted in fine content, they contain minor interbeds of sand- or silt-size vitric ash. Of the 12 ash layers analyzed at UICDoGS, 4 were taken from the Quaternary 30-m-thick surface layer.

\section{Quaternary Rift-basin Fill (Sites 790 and 791)}

For two sites situated so closely together, the thicknesses of the rift-basin sediments are remarkably different: $267 \mathrm{~m}$ at Site 790 , and $834 \mathrm{~m}$, or three orders of magnitude thicker, at Site 791. Initial sedimentation rates were 90 and $344 \mathrm{~m} / \mathrm{m} . y$. at Sites 790 and 791, respectively; at some time between 0.07 and $0.13 \mathrm{Ma}$ (Nishimura et al., this volume), the respective rates increased to 344 and $2200 \mathrm{~m} / \mathrm{m}$.y. (Fig. 3). The greater overburden pressures of the thicker column at Site 791 have compacted and lithified its basal sediments, whereas the sedimentary accumulation at Site 790 is entirely unlithified.

Table 1. Inventory of samples analyzed.

\begin{tabular}{|c|c|c|c|c|c|c|}
\hline \multirow[b]{2}{*}{ Site } & \multirow[b]{2}{*}{ Unit } & \multicolumn{2}{|c|}{ UICDoGS } & \multicolumn{2}{|c|}{ IGSU } & \multirow[b]{2}{*}{ Remarks } \\
\hline & & Samples & Analyses & Samples & Analyses & \\
\hline \multirow[t]{2}{*}{788} & I & 12 & 172 & 0 & 0 & All from coarse pumiceous layers \\
\hline & II & $\begin{array}{r}0 \\
12\end{array}$ & 0 & 0 & 0 & Thick numice heds and thin ashes \\
\hline 790 & II & $\begin{array}{r}12 \\
5\end{array}$ & $\begin{array}{r}142 \\
46\end{array}$ & $\begin{array}{l}49 \\
12\end{array}$ & $\begin{array}{r}514 \\
92\end{array}$ & Thin ashes only \\
\hline \multirow[t]{2}{*}{791} & I & 10 & 138 & 25 & 281 & Thick pumice beds and thin ashes \\
\hline & II & 5 & 44 & 0 & 0 & Thin ashes only \\
\hline
\end{tabular}


Unit II, which began accumulating at $1.1 \mathrm{Ma}$ and ceased being deposited at $0.131 \mathrm{Ma}$, or possibly at $0.102 \mathrm{Ma}$ (Nishimura et al., 1991), consists of burrowed nannofossil-rich clay, silty clay, and clayey silt, $106 \mathrm{~m}$ thick at Site 790 (271-165 mbsf). These lithologies are lithified at Site 791, where the unit is $406 \mathrm{~m}$ thick ( $834-428 \mathrm{mbsf}$ ). Bedding in Unit II is subhorizontal at Site 790. At Site 791, however, dips are $45^{\circ}$ at $760 \mathrm{mbsf}$ and gradually decrease upward to only $15^{\circ}-20^{\circ}$ at about $600 \mathrm{mbsf}$. We sampled and analyzed 22 thin ash layers in this subunit from Sites 790 and 791; how many of these samples come from correlatable layers at the two holes is not known.

Unit I, overlying Unit II 165 mbsf at Site 790 and 428 mbsf at Site 791, was deposited after 0.131 or $0.102 \mathrm{Ma}$, and consists mainly of thick units that consist of pumiceous tephra and vitric ash of sand and silt sizes, in layers 8-37 m thick at Site 790 and 29-118 $\mathrm{m}$ thick at Site 791. Elsewhere in this volume, these deposits are discussed more completely by Nishimura et al., whose nomenclature we have adopted by assigning to the thick pumiceous layers the numbers P-I to P-V in downward succession. These volcaniclastic layers are intercalated with thinner intervals that consist primarily of clay-nannofossil hemipelagites. Naming the surface 10-20-cm mud line hemipelagic deposit $\mathrm{H}-1$, we have labeled these intercalations $\mathrm{H}-2$ to $\mathrm{H}-5$ in order of increasing depth in the cores. The hemipelagic intervals are $3.0-15.5 \mathrm{~m}$ thick at Site 790, where recovery from Unit I was excellent. Recovery was not as good at Site 791, and so the thicknesses of the pumiceous and hemipelagic intervals are not as well known, especially at the bottom of the unit. Nishimura et al. (1991, and this volume) interpret the massive pumiceous layers as essentially instantaneous deposits from massive rhyolitic eruptive episodes separated by quiescent intervals that each lasted about $30,000 \mathrm{yr}$. Data for Unit I in the present report include analyses of glass shards from 60 samples $(32$ from Site 790 and 28 from Site 791) taken from the massive pumice layers as well as 35 samples ( 28 from 790,7 from 791 ) from thin ash layers within the hemipelagic intervals.

\section{ANALYTICAL METHODS}

At UICDoGS, all the samples were examined under a petrographic microscope to determine (1) the modal percentages of lithic, crystal, and glass grains; (2) the relative percentages of colored and colorless glass; (3) the size ranges and morphologies of the glass shards; and (4) the clay and fossil fractions (Table 2). All samples containing common glass shards large enough to analyze (at least $20 \mu \mathrm{m}$ in diameter) were selected for detailed chemical analysis. From each of these samples, 5-12 glass shards of each color and morphology were handpicked, air dried, affixed to an epoxy mounting ring, polished, and carbon coated.

The chemical composition of each glass shard was obtained using a JEOL 35CF scanning electron microscope (SEM) equipped with a Tracor Northern Microanalyzer energy-dispersive spectrometer (EDS). Fourteen elements ( $\mathrm{Si}, \mathrm{Ti}, \mathrm{Al}, \mathrm{Fe}, \mathrm{Mn}, \mathrm{Mg}, \mathrm{Ca}, \mathrm{Na}, \mathrm{K}, \mathrm{P}, \mathrm{Cr}, \mathrm{Ni}, \mathrm{S}$ and $\mathrm{Cl})$ were analyzed. Operating conditions were $15 \mathrm{kV}$ accelerating voltage, $0.8 \mathrm{nA}$ beam current, and 100 -s count time. Preliminary focused-spot analyses showed decreases in $\mathrm{Na}$ and $\mathrm{K}$ count rates; accordingly, to reduce alkali volatilization, we adopted the standard procedure of rastering the electron beam over square areas from 10 to $20 \mu \mathrm{m}$ on the side. All data (except for $\mathrm{Cl}$ ) were reduced to oxide

Table 2. Components, size ranges, and morphology of glass shards in samples analyzed at UICDoGS.

\begin{tabular}{|c|c|c|c|c|c|c|c|c|c|c|c|}
\hline \multirow{3}{*}{$\begin{array}{l}\text { Core, section, } \\
\text { interval }(\mathrm{cm})\end{array}$} & \multirow{3}{*}{$\begin{array}{l}\text { Depth } \\
\text { (mbsf) }\end{array}$} & \multicolumn{4}{|c|}{ Composition (\%) } & & & & & & \\
\hline & & \multirow[b]{2}{*}{ Glass } & \multirow[b]{2}{*}{ Crystal } & \multirow[b]{2}{*}{ Lithics } & \multirow{2}{*}{$\begin{array}{c}\text { Clay } \\
\text { and } \\
\text { fossils }\end{array}$} & \multicolumn{2}{|c|}{ Relative glass (\%) } & \multicolumn{2}{|c|}{ Glass shard size range ( $\mathrm{mm}$ ) } & \multicolumn{2}{|c|}{ Glass shard morphology } \\
\hline & & & & & & Colorless & Brown & Colorless & Brown & Colorless & Brown \\
\hline $120-788 \mathrm{C}-1 \mathrm{H}-2,70-72$ & 6.20 & 94.26 & 4.76 & 0.95 & 0.00 & 96.97 & 3.03 & $<0.015-2.000$ & $0.125-0.500$ & $\mathrm{Pm}=\mathrm{Bbw}$ & BIVs \\
\hline $120-788 \mathrm{C}-2 \mathrm{H}-1,36-38$ & 13.66 & 80.28 & 18.31 & 1.41 & 0.00 & 85.09 & 14.91 & $0.015-1.000$ & $0.125-1.000$ & $\mathrm{Pm} \gg \mathrm{B} b \mathrm{w} \gg>\mathrm{B} 1$ & BIVs \\
\hline $120-788 \mathrm{~A}-4 \mathrm{R}-1,11-12$ & 26.31 & 86.67 & 10.91 & 2.42 & 0.00 & 91.61 & 8.39 & $0.015-0.500$ & $0.031-0.500$ & $\mathrm{Pm}>\mathrm{Bbw}>>\mathrm{B} \mid$ & BISvs $>\mathrm{Tb}$ \\
\hline $120-788 \mathrm{C}-3 \mathrm{H}-6,98-100$ & 28.68 & 82.24 & 11.84 & 5.92 & 0.00 & 98.40 & 1.60 & $<0.015-1.000$ & $0.063-0.500$ & $\mathrm{Bbw}=\mathrm{Pm} \gg \mathrm{BI}$ & BISvs \\
\hline $120-788 \mathrm{C}-4 \mathrm{H}-4,24-26$ & 34.44 & 72.73 & 10.39 & 1.95 & 14.94 & 90.18 & 9.82 & $<0.015-4.000$ & $0.063-1.000$ & $\mathrm{Bbw}>\mathrm{Pm}>\mathrm{Bl}$ & BISvs $>\mathrm{Tb}$ \\
\hline $120-788 \mathrm{C}-5 \mathrm{H}-5,60-62$ & 45.80 & 96.23 & 3.14 & 0.63 & 0.00 & 99.35 & 0.65 & $<0.015-2.000$ & $0.250-0.500$ & $\mathrm{Bbw}>\mathrm{Pm}$ & BlSvs \\
\hline $120-788 \mathrm{C}-8 \mathrm{H}-2,73-75$ & 69.93 & 87.93 & 10.34 & 1.72 & 0.00 & 58.82 & 41.18 & $0.015-1.000$ & $0.063-0.500$ & $\mathrm{Pm}>\mathrm{Bbw} \gg>\mathrm{B} \mid$ & BISvs $>\mathrm{Tb}$ \\
\hline $120-788 \mathrm{C}-10 \mathrm{H}-4,124-126$ & 92.44 & 97.76 & 2.24 & 0.00 & 0.00 & 99.24 & 0.76 & $<0.015-4.000$ & $0.250-0.500$ & $\mathrm{Pm}>\mathrm{Bbw} \gg>\mathrm{Bl}$ & BlVs \\
\hline $120-788 \mathrm{C}-13 \mathrm{H}-5,14-16$ & 121.34 & 89.02 & 9.76 & 1.22 & 0.00 & 93.15 & 6.85 & $<0.015-2.000$ & $0.125-1.000$ & $\mathrm{Pm}=\mathrm{Bbw} \gg \mathrm{Bl}$ & BlVs $>\mathrm{Tb}$ \\
\hline $120-788 \mathrm{C}-17 \mathrm{H}-1,59-61$ & 153.79 & 82.31 & 15.65 & 2.04 & 0.00 & 98.35 & 1.65 & $<0.015-2.000$ & $0.125-0.500$ & $\mathrm{Bbw}>\mathrm{Pm}>\mathrm{Bl}$ & BIVs \\
\hline $120-788 \mathrm{C}-21 \mathrm{H}-1,30-32$ & 191.50 & 80.94 & 17.89 & 1.63 & 0.00 & 80.81 & 19.19 & $<0.015-0.500$ & $0.063-0.500$ & $\mathrm{Bbw}>\mathrm{Pm}>\mathrm{B} 1$ & BlVs \\
\hline $120-788 \mathrm{C}-26 \mathrm{H}-1,2-4$ & 238.72 & 87.18 & 11.97 & 0.85 & 0.00 & 98.04 & 1.96 & $<0.015-2.000$ & $0.250-0.500$ & $\mathrm{Pm}>\mathrm{Bbw}>\mathrm{Bl}$ & BiVs \\
\hline $120-790 \mathrm{~A}-1 \mathrm{H}-3,145-147$ & 4.45 & 90.64 & 4.68 & 1.75 & 2.92 & 95.48 & 4.52 & $0.015-2.000$ & $0.063-0.250$ & $\mathrm{Pm}=\mathrm{Bbw}$ & BiSvs \\
\hline $120-790 \mathrm{~A}-2 \mathrm{H}-6,5-7$ & 16.35 & 84.92 & 13.97 & 0.56 & 0.56 & 57.24 & 42.76 & $0.015-0.125$ & $0.015-0.250$ & $\mathrm{Bbw}>\mathrm{Pm}$ & BISvs \\
\hline $120-790 \mathrm{~B}-4 \mathrm{H}-6,59-61$ & 31.59 & 92.94 & 5.29 & 0.59 & 1.18 & 94.30 & 5.70 & $0.015-0.500$ & $0.063-0.125$ & $\mathrm{~B} b \mathrm{w}>\mathrm{Pm} \gg>\mathrm{B} 1$ & BlVs \\
\hline $120-790 \mathrm{~A}-4 \mathrm{H}-4,120-122$ & 33.50 & 82.49 & 16.38 & 0.00 & 1.13 & 87.67 & 12.33 & $0.015-2.000$ & $0.063-1.000$ & $\mathrm{Bbw}>\mathrm{Pm} \gg>\mathrm{Bb}$ & BlHvs \\
\hline $120-790 \mathrm{~B}-8 \mathrm{H}-3,144-146$ & 66.04 & 63.52 & 25.79 & 7.55 & 3.14 & 76.24 & 23.76 & $0.015-0.250$ & $0.015-0.250$ & $\mathrm{Pm}>\mathrm{Bbw}$ & BiSvs \\
\hline $120-790 \mathrm{~B}-8 \mathrm{H}-5,124-126$ & 68.84 & 62.01 & 29.61 & 7.82 & 0.56 & 2.70 & 97.30 & $0.125-0.250$ & $0.031-1.000$ & $\mathrm{Pm}$ & BlHvs $\gg \mathrm{Tb}$ \\
\hline $120-790 \mathrm{~B}-10 \mathrm{H}-5,23-25$ & 87.23 & 64.86 & 11.49 & 4.05 & 19.59 & 98.96 & 1.04 & $<0.015-0.250$ & $0.063-0.125$ & $\mathrm{Bbw} \gg \mathrm{Pm}$ & BISvs \\
\hline $120-790 \mathrm{C}-3 \mathrm{H}-4,56-58$ & 109.26 & 98.39 & 1.61 & 0.00 & 0.00 & 100.00 & 0.00 & $0.015-0.125$ & & $\mathrm{Bbw} \gg \mathrm{Pm}$ & \\
\hline $120-790 \mathrm{C}-4 \mathrm{H}-4,114-116$ & 119.54 & 83.12 & 14.29 & 2.60 & 0.00 & 98.44 & 1.56 & $<0.015-2.000$ & $0.250-1.000$ & $\mathrm{Bbw}>\mathrm{Pm} \gg>\mathrm{B} 1$ & BlVs \\
\hline $120-790 \mathrm{C}-6 \mathrm{H}-1,28-30$ & 133.48 & 97.04 & 2.96 & 0.00 & 0.00 & 99.39 & 0.61 & $0.015-0.500$ & $0.125-0.500$ & $\mathrm{Bbw}>\mathrm{Pm}$ & BiSvs \\
\hline $120-790 \mathrm{C}-6 \mathrm{H}-4,47-49$ & 138.17 & 77.56 & 17.31 & 5.13 & 0.00 & 90.08 & 9.92 & $0.015-0.500$ & $0.063-0.250$ & $\mathrm{Pm}=\mathrm{Bbw}>\mathrm{Bl}$ & BlSvs \\
\hline $120-790 \mathrm{C}-6 \mathrm{H}-5,114-116$ & 140.34 & 71.43 & 17.03 & 7.69 & 3.85 & 80.77 & 19.23 & $<0.015-0.500$ & $0.031-0.250$ & $\mathrm{Bbw}>\mathrm{Pm}>\mathrm{BI}$ & BlSvs \\
\hline $120-790 \mathrm{C}-11 \mathrm{X}-3,25-27$ & 177.85 & 95.97 & 0.81 & 0.00 & 3.23 & 100.00 & 0.00 & $<0.015-0.500$ & & $\mathrm{Bbw} \gg \mathrm{Pm}$ & \\
\hline $120-790 \mathrm{C}-13 \mathrm{X}-1,50-52$ & 194.40 & 82.67 & 12.67 & 4.00 & 0.67 & 87.10 & 12.90 & $<0.015-0.500$ & $0.031-0.500$ & $\mathrm{Bbw} \gg \mathrm{Pm} \gg \mathrm{Bl}$ & $\mathrm{BISvs}>\mathrm{Tb}$ \\
\hline $120-790 \mathrm{C}-14 \mathrm{X}-1,140-142$ & 206.50 & 70.00 & 28.13 & 1.25 & 0.63 & 2.68 & 97.32 & $0.015-2.000$ & $0.015-0.063$ & Bbw & BiSvs \\
\hline $120-790 \mathrm{C}-17 \mathrm{X}-1,141-145$ & 233.81 & 82.39 & 9.86 & 3.52 & 4.23 & 100.00 & 0.00 & $<0.015-0.500$ & & $\mathrm{Bbw}>\mathrm{Pm}$ & \\
\hline $120-790 \mathrm{C}-19 \times-4,129-133$ & 257.49 & 76.67 & 10.00 & 7.50 & 5.83 & 2.17 & 97.83 & $0.031-0.125$ & $0.015-1.000$ & Bbw & BIVs \\
\hline $120-791 \mathrm{~A}-2 \mathrm{H}-4,133-135$ & 10.33 & 96.43 & 2.14 & 0.00 & 1.43 & 99.26 & 0.74 & $<0.015-0.125$ & $0.031-0.063$ & $\mathrm{Bbw}>\mathrm{Pm}$ & \\
\hline $120-791$ A $-5 \mathrm{H}-6,19-21$ & 40.69 & 95.00 & 3.13 & 0.63 & 1.25 & 96.05 & 3.95 & $0.015-0.500$ & $0.031-0.250$ & $\mathrm{Bbw}>\mathrm{Pm} \gg>\mathrm{B} 1$ & BiSvs \\
\hline $120-791 \mathrm{~A}-8 \mathrm{H}-5,29-31$ & 67.89 & 90.29 & 7.43 & 1.14 & 1.14 & 94.30 & 5.70 & $<0.015-1.000$ & $0.031-0.500$ & $\mathrm{Bbw}>\mathrm{Pm} \gg>\mathrm{Bl}$ & BISvs \\
\hline $120-791 \mathrm{~A}-15 \mathrm{H}-3,20-22$ & 132.70 & 94.65 & 4.81 & 0.00 & 0.53 & 96.61 & 3.39 & $<0.015-0.500$ & $0.015-0.063$ & $\mathrm{Bbw}>\mathrm{Pm}$ & B1Svs \\
\hline $120-791 \mathrm{~A}-16 \mathrm{H}-6,110-112$ & 147.80 & 77.35 & 13.25 & 2.14 & 7.26 & 86.74 & 13.26 & $<0.015-2.000$ & $0.015-1.000$ & $\mathrm{Bbw}>\mathrm{Pm}$ & BlVsTb \\
\hline $120-791 \mathrm{~A}-22 \mathrm{H}-6,35-37$ & 204.75 & 97.41 & 2.59 & 0.00 & 0.00 & 100.00 & 0.00 & $<0.015-4.000$ & & $\mathrm{Bbw}>\mathrm{Pm}$ & \\
\hline $120-791 \mathrm{~A}-30 \mathrm{X}-\mathrm{CC}, 7-9$ & 265.37 & 93.71 & 6.29 & 0.00 & 0.00 & 96.64 & 3.36 & $<0.015-0.500$ & $0.031-0.250$ & $\mathrm{Bbw}>\mathrm{Pm}$ & BISvs \\
\hline $120-791 \mathrm{~A}-34 \mathrm{X}-1,22-24$ & 304.22 & 95.76 & 1.82 & 0.61 & 1.82 & 99.37 & 0.63 & $<0.015-0.500$ & $0.063-0.125$ & $\mathrm{Bbw}>\mathrm{Pm}$ & BISvs \\
\hline $120-791 \mathrm{~A}-39 \mathrm{X}-1,51-53$ & 352.81 & 87.85 & 6.08 & 1.66 & 4.42 & 94.97 & 5.03 & $<0.015-0.125$ & $0.015-0.063$ & $\mathrm{Bbw} \gg \mathrm{Pm}$ & BISvs $>\mathrm{Tb}$ \\
\hline $120-791 \mathrm{~A}-42 \mathrm{X}-1,22-24$ & 381.62 & 92.12 & 3.03 & 0.00 & 4.85 & 98.68 & 1.32 & $<0.015-0.125$ & $0.015-0.125$ & $\mathrm{Bbw} \gg \mathrm{Pm}$ & BISvs \\
\hline $120-791 \mathrm{~B}-13 \mathrm{R}-2,54-56$ & 504.14 & 81.33 & 3.01 & 0.60 & 15.06 & 97.78 & 2.22 & $<0.015-0.125$ & $0.031-0.063$ & $\mathrm{Bbw} \gg \mathrm{Pm}$ & BlSvs \\
\hline $120-791 \mathrm{~B}-20 \mathrm{R}-1,2-3$ & 569.72 & 81.41 & 0.64 & 0.00 & 17.95 & 100.00 & 0.00 & $<0.015-0.063$ & & $\mathrm{Bbw} \gg \mathrm{Pm}$ & \\
\hline $120-791$ B- $28 \mathrm{R}-4,79-81$ & 651.89 & 70.48 & 3.01 & 0.00 & 26.51 & 99.15 & 0.85 & $<0.015-0.250$ & $0.015-0.031$ & $\mathrm{Bbw} \gg \mathrm{Pm}$ & BISvs \\
\hline $120-791 \mathrm{~B}-40 \mathrm{R}-1,34-35$ & 762.74 & 65.29 & 9.92 & 4.96 & 19.83 & 34.18 & 65.82 & $0.015-0.125$ & $0.015-1.000$ & $\mathrm{Bbw}>\mathrm{Pm}$ & BIVs \\
\hline $120-791 \mathrm{~B}-46 \mathrm{R}-2,12-14$ & 821.62 & 75.30 & 3.01 & 0.00 & 21.69 & 96.00 & 4.00 & $<0.015-0.250$ & $0.031-0.125$ & $\mathrm{Bbw}>\mathrm{Pm}$ & BiSvs \\
\hline
\end{tabular}

Notes: $\mathrm{Pm}=$ pumice, $\mathrm{Bbw}=$ bubble-wall, $\mathrm{BI}=$ blocky, Svs $=$ slightly vesicular $(<10 \%), \mathrm{Vs}=$ vesicular $(10 \%-30 \%)$, Hvs $=$ highly vesicular $(>30 \%)$, and $\mathrm{Tb}=$ tabular. 
weight percentages using Bence and Albee (1968) correction factors. Total Fe is reported as $\mathrm{FeO}$. The reference spectrum for each element was obtained using laboratory mineral standards. Initially, after calibration of the spectrum with the Juan de Fuca Glass Standard 6, a rhyolite standard (Yellowstone Park rhyolite) was analyzed (Table 3). The test results varied in only minor ways from the published percentages, except for $\mathrm{TiO}_{2}$ and $\mathrm{CaO}$, which, being of low absolute abundances, differed significantly. Accordingly, we used the Juan de Fuca glass as a calibration reference between every 15 to 20 of our Izu-Bonin analyses. Estimated errors in our results are $<5 \%$, except for $\mathrm{Mn}$ and $\mathrm{P}$ (Table 3 ), which, accordingly, we do not evaluate in this report.

An additional 86 samples, of which the great majority $(61$, or $71 \%)$ were taken from the 5 thick pumiceous beds in the rift basin successions, were analyzed at IGSU using a JEOL Model JCXA-733 electron probe microanalyzer with $15-\mathrm{kV}$ accelerating voltage, a beam current of $12 \mathrm{nA}$, and 10-s counting times per element. An average of $11(2-41)$ grains from each sample were analyzed. Oxide data are reported as averages that are accurate to within $1 \%$. We measured 13 elements at IGSU; compared with the set analyzed at UICDoGS, $\mathrm{P}$ and $\mathrm{Cl}$ were omitted, and V was added. These 3 elements are typically either absent or present in very low abundances, and so the data for individual oxides in the UICDoGS and IGSU sets appear quite compatible, with one exception: magnesium tends to be systematically higher by about $0.2 \%$ in the IGSU data. All the oxide data, normalized to $100 \%$, are summarized and averaged for each suite in each layer, and are presented in the Appendix (back-pocket microfiche).

\section{Systematic Weight Loss}

Many workers have previously noted that the oxides determined by electron probe for deep-sea glasses normally do not account for the total weight of the material, falling short by several percent. This is especially true for glasses of rhyolitic composition, in which the summed oxides fall short of $100 \%$ by as much as $10 \%$, and typically by $4 \%-6 \%$ (Ninkovitch, 1979; Cadet et al., 1982; Pouclet et al., 1985, 1986). Our data show similar weight shortfalls, as we illustrate (Fig. 4), using only the UICDoGS data to avoid introducing artifacts that may arise from the minor instrumental, methodological, and computational differences between the UICDoGS and IGSU analyses.

\section{Colorless Glasses (Rhyolites)}

At Site 788 , most analyses show weight losses of $4 \%-8 \%$. At Site 790 , typical weight losses are $3 \%-7 \%$ at depths greater than $87 \mathrm{mbsf}$ (although the values are only $0.5-3 \mathrm{wt} \%$ for some samples, including a group of three ash beds in the depth interval 133.48-140.34 mbsf); above $87 \mathrm{mbsf}$, weight losses are all $<3 \%$. At Site 791, most Unit II glasses have weight losses of $3 \%-9 \%$; the one exception $(1 \%-5 \%)$ has only about $70 \%$ silica at the lower compositional end for rhyolites.
Unit I shows a pronounced upward decrease in weight loss, from $5 \%-7 \%$ to $0 \%-2 \%$.

\section{Brown Glasses (Dacites to Basalts)}

At Site 788 , most weight losses are only $0.5 \%-4.5 \%$, and most of those at the upper end of this range $(>2.5 \%)$ are dacites. At Site 790 , weight losses do not exceed 3\%, and at Site 791 , all are $<2.5 \%$.

For all sites independent of depth and shard color (Fig. 4, right panels), almost all samples with $>3 \%$ weight loss have silica contents in excess of $70 \%$. All the shards from the flank site that contain $>70 \%$ silica show weight losses $>3 \%$, but some high-silica shards from Sites 790 and 791 contents display weight losses that are $<3 \%$.

\section{RESULTS}

\section{Flank Site (Site 788)}

Figure 5 shows that all the shards from Site 788 belong to the low-K arc tholeiite suite as defined by Peccerillo and Taylor (1976). In the Pliocene deposits (Fig. 6), approximately half of the samples are virtually pure rhyolites, with $<2 \%$ of the shards being more mafic. The other half of the samples are trimodal; besides rhyolite, they contain generally minor amounts $(<0.65 \%-1.96 \%)$ of dacite and andesite, or andesite and either basaltic andesite or basalt (Table 2). In every trimodal sample, percentages of types decrease systematically with silica content. Dark glass is abnormally abundant in only two layers: one at 69.93 mbsf contains $41 \%$ andesitic and rare basaltic shards; in another, at $191.5 \mathrm{mbsf}$, andesites and rare basaltic andesites compose $19 \%$ of the glasses. Upward trends in the rhyolites from 150 mbsf to below the unconformity $(34.44 \mathrm{mbsf})$ include a strong decrease in potassium and a slight decrease in silica, and slight increases in titanium, aluminum, iron, and calcium.

The only significant difference between the Pliocene and Quaternary deposits of Site 788 is that the basalts and basaltic andesites occur only in the Pliocene; the least silicic glasses in the Quaternary deposits are andesites. In the Quaternary deposits, the glasses tend to be polymodal, but they are still dominantly rhyolitic. The uppermost three samples show slight increases in titanium, iron, and magnesium. As will be seen, this uppermost flank sequence is compositionally similar to the thick pumice layers of Unit I in the basin sites, especially $\mathrm{P}-\mathrm{II}$ and P-IV.

\section{Rift-basin Sites}

Unlike the results from the flank site, analyses from the rift-basin sites come from two distinct sample types. The most prominent of these comprises the thick pumice layers P-I to P-V of Unit I, which, although more enriched in fines, are textually comparable with the flank samples. The second type comprises discrete thin ash layers in

Table 3. Analyes of \#69 Yellowstone National Park Rhyolite Glass (USNM 72854) and \#66 Juan de Fuca Ridge Basaltic Glass 6 (USNM 111240/52).

\begin{tabular}{|c|c|c|c|c|c|c|c|c|}
\hline & \multicolumn{3}{|c|}{$\begin{array}{l}\text { \#69 Yellowstone Park rhyolite } \\
\text { (this study; } N=10 \text { ) }\end{array}$} & \multicolumn{5}{|c|}{$\begin{array}{l}\text { \#66 Juan de Fuca basaltic glass } 6 \\
\text { (this study; } N=67 \text { ) }\end{array}$} \\
\hline & Average & Standard & Published & Average & Standard & Published & $\begin{array}{l}\text { Accuracy } \\
(\%)\end{array}$ & $\begin{array}{l}\text { Precision } \\
(\%)\end{array}$ \\
\hline $\mathrm{SiO}_{2}$ & 76.99 & 0.37 & 76.81 & 50.78 & 0.28 & 50.81 & 0.05 & 0.55 \\
\hline $\mathrm{TiO}_{2}$ & $* 0.02$ & 0.05 & $\begin{array}{l}0.01 \\
0.12\end{array}$ & $\begin{array}{r}30.7 \% \\
1.85\end{array}$ & 0.12 & $\begin{array}{l}30.01 \\
1.85\end{array}$ & 0.16 & *6.48 \\
\hline $\mathrm{Al}_{2} \mathrm{O}_{3}$ & 12.10 & 0.18 & 12.06 & 14.07 & 0.22 & 14.06 & 0.06 & 1.56 \\
\hline $\mathrm{FeO}$ & 1.15 & 0.09 & 1.23 & 11.85 & 0.21 & 11.84 & 0.09 & 1.77 \\
\hline $\mathrm{MnO}$ & 0.04 & 0.07 & 0.03 & 0.19 & 0.08 & 0.22 & $*-12.62$ & $* 42.00$ \\
\hline $\mathrm{MgO}$ & 0.00 & 0.00 & $<0.01$ & 6.71 & 0.15 & 6.71 & 0.01 & 2.23 \\
\hline $\mathrm{CaO}$ & 0.42 & 0.06 & 0.50 & 11.11 & 0.17 & 11.12 & 0.05 & 1.53 \\
\hline $\mathrm{Na}_{2} \mathrm{O}$ & 3.69 & 0.08 & 3.75 & 2.62 & 0.13 & 2.62 & 0.01 & 4.96 \\
\hline $\mathrm{K}_{2} \mathrm{O}$ & 4.80 & 0.07 & 4.89 & 0.18 & 0.04 & 0.19 & -4.63 & 22.00 \\
\hline $\mathrm{P}_{2} \mathrm{O}_{5}$ & 0.00 & 0.00 & $<0.01$ & 0.14 & 0.17 & 0.20 & $*-28.66$ & $* 121.42$ \\
\hline $\mathrm{Cl}^{3}$ & 0.09 & 0.03 & 0.13 & & & & & \\
\hline
\end{tabular}

Note: $N=$ number of samples.

*The apparent large errors for these elements are attributable to their low absolute contents. 


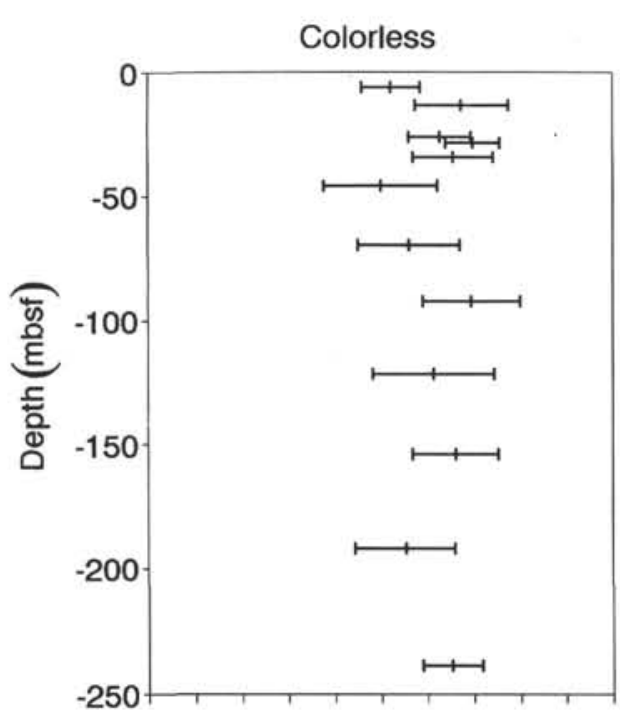

Brown SITE 788
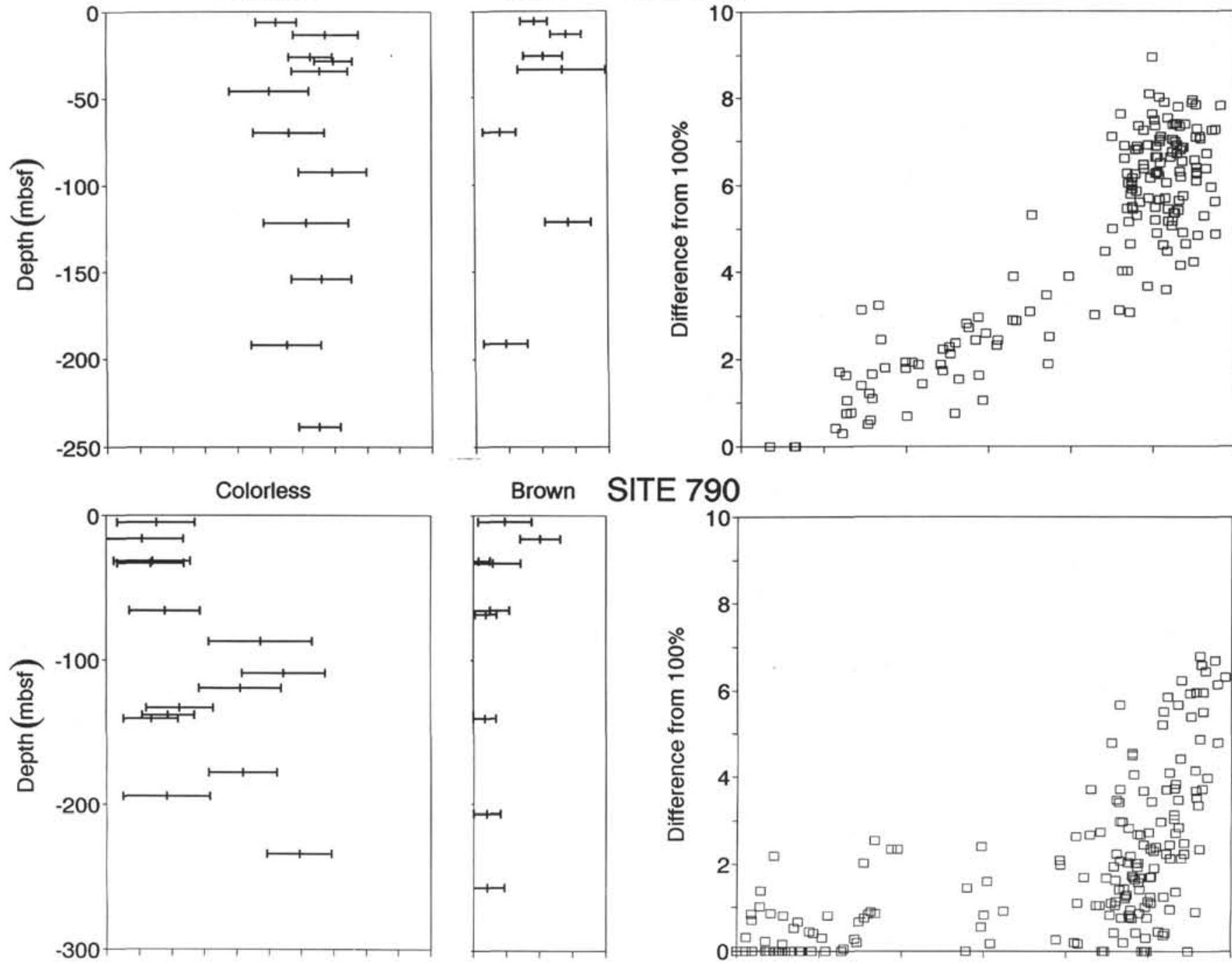

\section{Brown SITE 790}
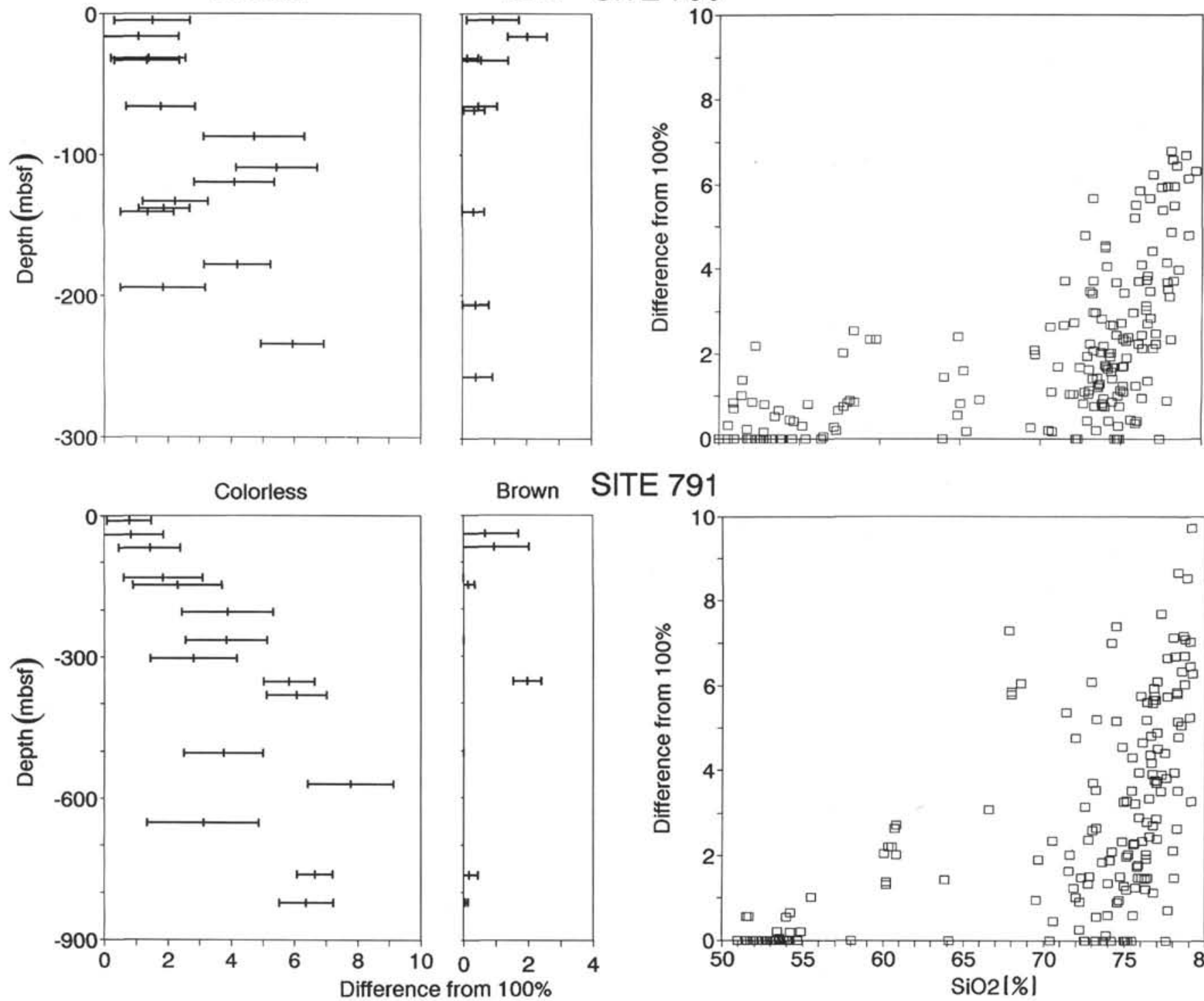

\section{SITE 791}

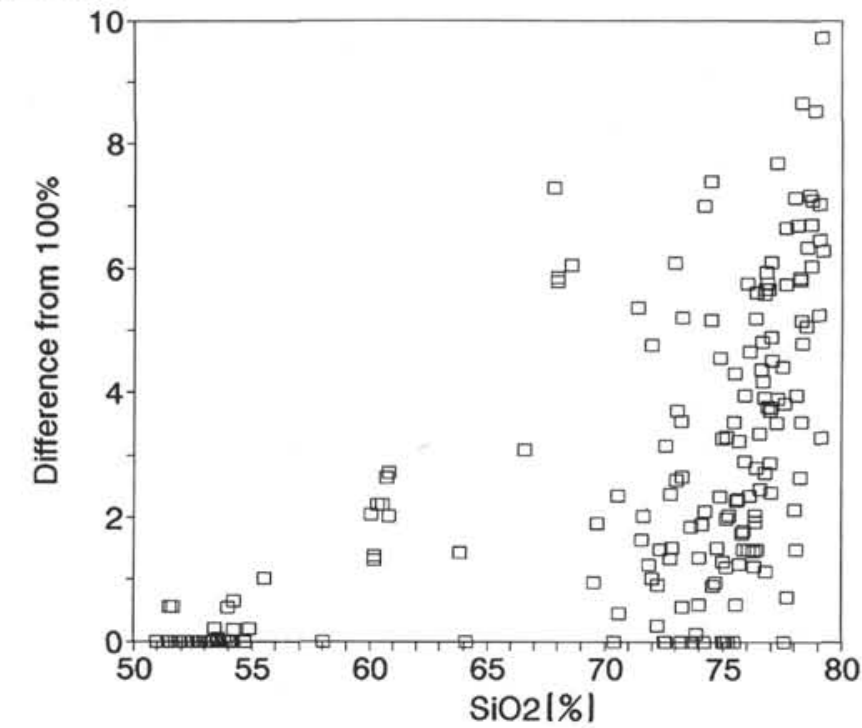

Figure 4. Weight loss at all sites (UICDoGS data only). Left and center panels = variation in weight loss with depth (mbsf). Each line represents \pm 1 standard deviation (SD) from the indicated average. Right panels = weight loss vs. $\mathrm{SiO}_{2}$ (normalized to $100 \%$ ). 

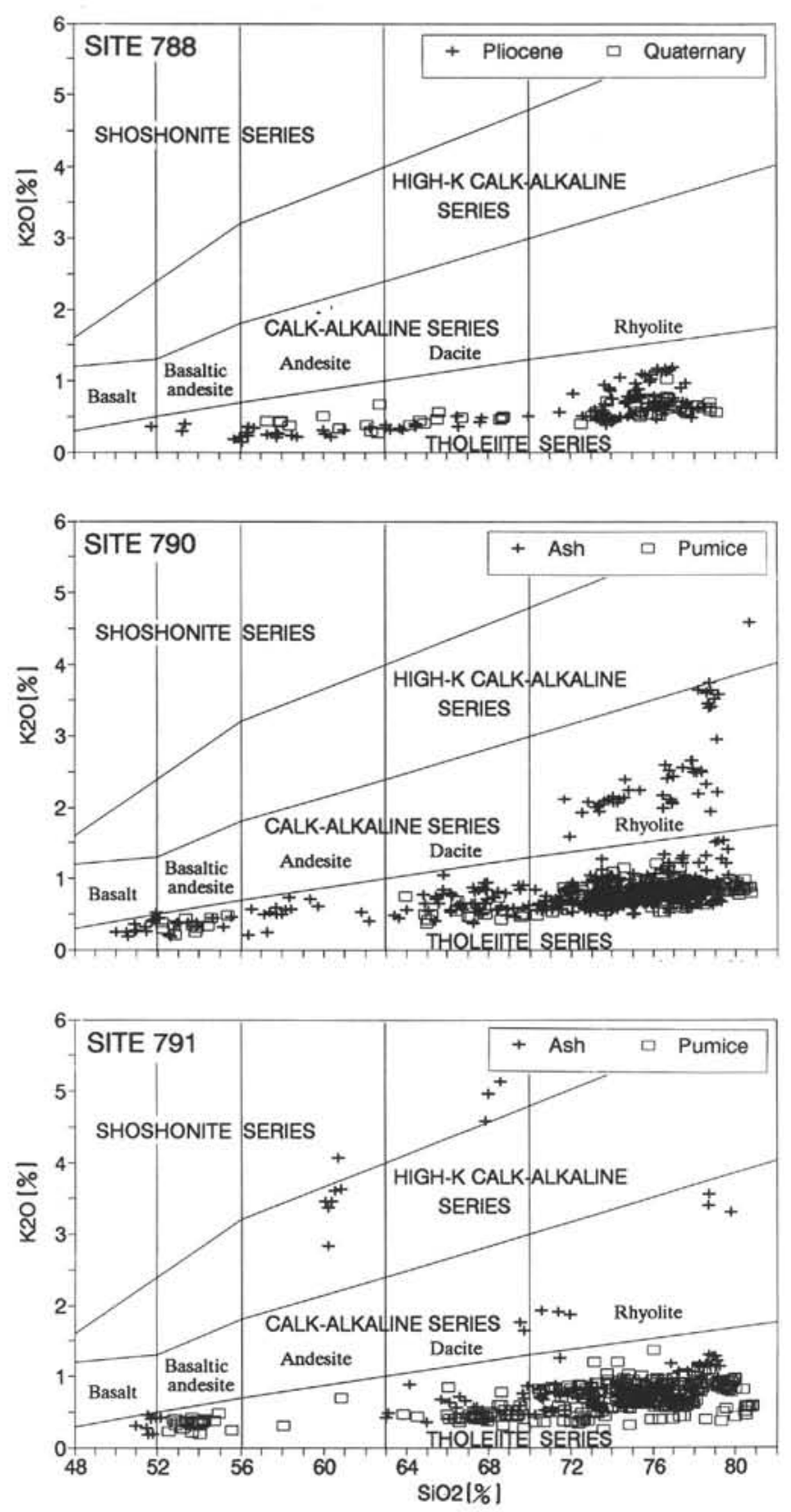

Figure 5. $\mathrm{SiO}_{2}-\mathrm{K}_{2} \mathrm{O}$ variation diagrams for the three sites. Suite boundaries from Peccerillo and Taylor (1976).

the hemipelagic successions, both in Unit II and in Layers H-2 to H-5 intercalated between the thick pumice beds of Unit I.

\section{Thick Pumice Layers}

Compositionally, the thick pumice layers closely approximate those of Site 788; most belong to the low-K arc tholeiite suite, strongly dominated by rhyolites (Figs. 5 and 7). The results from Site 790 show two general upward compositional trends (Fig. 7). First, more mafic varieties appear: $\mathrm{P}-\mathrm{V}$ is exclusively rhyolite; all the others have dacitic components; and P-II and P-I have, in addition to dacites, shards of basaltic andesite composition. Second, the rhyolites and dacites tend to become less silicic. At Site 791, the succession appears composi- tionally more homogeneous, although the lowermost two layers (P-V and IV) are more silicic than the others, and the dacites in Layers P-III and P-II show a similar upward trend of decreasing silica.

\section{Thin Ash Layers}

Compared with those of the thick pumice layers, the compositions of the thin ash layers are more variable (Fig. 8), although they are also dominated by low-K rhyolites. The base of the volcaniclastic successions at both sites have more mafic constituents. At Site 790, a layer at 257.49 mbsf is virtually all brown basaltic scoria. At Site 791, an ash layer at $762.74 \mathrm{mbsf}$ is $66 \%$ brown basaltic glass and $34 \%$ clear rhyolitic glass. A basaltic ash at 206.5 mbsf in Site 790 has no equivalent in Site 791, possibly because of the poor recovery. The basaltic shards recovered at both sites have the following ranges in major oxide percentages: $\mathrm{TiO}_{2}, 1.01-1.65 ; \mathrm{Al}_{2} \mathrm{O}_{3}, 14.5-16.3 ; \mathrm{FeO}$, 9.98-12.1; $\mathrm{MgO}, 5.49-7.22 ; \mathrm{CaO}, 11.26-13.71 ; \mathrm{Na}_{2} \mathrm{O}, 1.85-3.02$; and $\mathrm{K}_{2} \mathrm{O}, 0.18-0.52$. An ash layer at Site 790 (68.84 mbsf) consists of basaltic andesite to andesite shards.

At both sites, shards with higher potassium contents occur in several thin layers (3-4 cm thick) of fine-grained (very fine sand to silt; 3.5-5.5 $\phi$ ), well-sorted ash (Fig. 8). A layer below the middle of Unit II in Site 791 (651.89 mbsf) is a minor stratigraphic maximum for potassium (1.8\%, or medium-K rhyolite). At Site 790 , a similar maximum occurs at approximately the same stratigraphic position ( $233.81 \mathrm{mbsf}$ ), although the potassium values here are only at the high end of the low-K range (1.4\%). An interval less than $4 \mathrm{~m}$ thick in the uppermost portion of Unit II at Site 790 (176.2-179.86 mbsf) contains four layers that are exclusively or dominantly medium-K rhyolites. Those at 176.2 and $177.85 \mathrm{mbsf}$ are virtually pure; those at 178.7 and 179.86 mbsf are mixed with low-K rhyolites that may have come from adjacent sediment. We cannot report equivalents of these layers at Site 791 because of the poor recovery there. The shards in the only ash layer analyzed in Interval H-5 at Site 791 are high-K andesites and dacites. In hemipelagite Interval $\mathrm{H}-3$, a distinct, very fine-grained, very well-sorted, white ash layer of medium-K rhyolites occurs 60.96 mbsf at Site 790, and at Site 791, a low-K ash layer (158.55 mbsf) contains $30 \%$ medium-K rhyolites. The higher-K rhyolites differ from those of lower potassium contents in having lower ranges in $\mathrm{FeO}(0.7 \%$ $4.9 \%$ vs. $1.5 \%-6.15 \%)$, and $\mathrm{CaO}(0.47 \%-3.92 \%$ vs. $1.4 \%-6.3 \%)$. In addition, $\mathrm{TiO}_{2}$ contents tend to be lower and $\mathrm{Al}_{2} \mathrm{O}_{3}$ contents higher.

\section{DISCUSSION AND CONCLUSIONS}

\section{Source of Systematic Weight Loss}

Following previous workers (Jones, 1973; Ninkovitch, 1979; Cadet et al., 1982; Pouclet et al., 1985, 1986), we assume that the differences in our analyzed glass shards between summed oxides and $100 \%$ primarily represent water contents vaporized during analysis, probably accompanied by minor losses caused by alkali vaporization. We are uncertain, however, as to how much of the lost water is magmatic and how much is hydrated. Hervig et al. (1989) have shown, by analyzing melt inclusions in air-subaerial fall tephra from two rhyolitic eruptions, that the original rhyolite magmas contained an average $4.3 \mathrm{wt} \%$ water $(2.9 \%-5.3 \%)$. Scheidegger et al. (1978), however, have pointed out that typical terrestrial glass shards contain less than $3 \%$ water, whereas analogous marine shards have $4.5 \%-5.5 \%$. In any case, although water content may increase by a factor of 2 during hydration, we believe that the other oxides remain essentially unaffected. Samples from the rift basin display a pronounced trend of increasing hydration with age. The greater degree of hydration of glasses from the flank site is best explained by their greater age; however, even the glasses from the uppermost (supra-hiatus) sediments of the flank site show greater hydration than the glasses of equivalent age from 

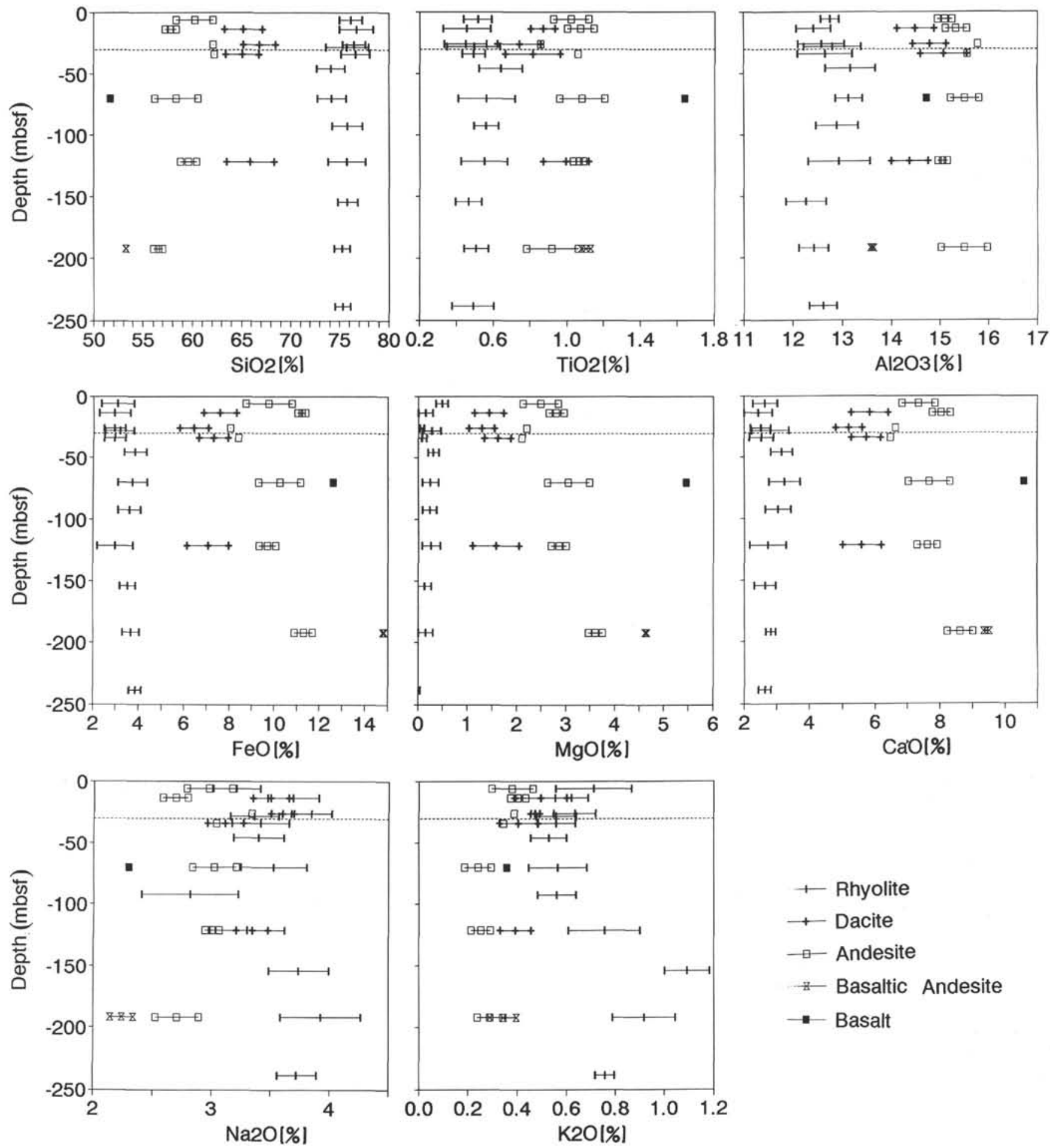

Figure 6. Major oxide stratigraphy at Site 788 on the rift flank uplift. Each line represents \pm 1 standard deviation (SD) from the indicated average. The dashed line indicates the biostratigraphically determined unconformity.

the rift-basin fill. This may be a consequence of prolonged exposure at the seafloor. The youngest rift-fill sediments are younger than the uppermost rift-flank sediments, which correlate geo-chemically either with thick pumice layer PII or PIV ( 31 and $67 \mathrm{Ka}$, respectively; Nishimura et al., this volume). In addition, the thick pumice layers of the rift fill are covered by, and interbedded with, clayey hemipelagic sediment that, owing to low permeability, may retard shard hydration, as suggested by Kobayashi (1984).

\section{Pre- and Syn-rift Volcanism}

Our results show that pre- and syn-rift volcanism were both dominated by rhyolitic explosive eruptions. This is unusual. Although andesites were formerly thought to dominate arc volcanism, work since the 1970s (cf. Hawkins et al., 1984, and references therein) has shown extensive basalts and basaltic andesites in the west Pacific, Caribbean, and Scotia arcs. The Izu-Bonin results show that, in 
SITE 790

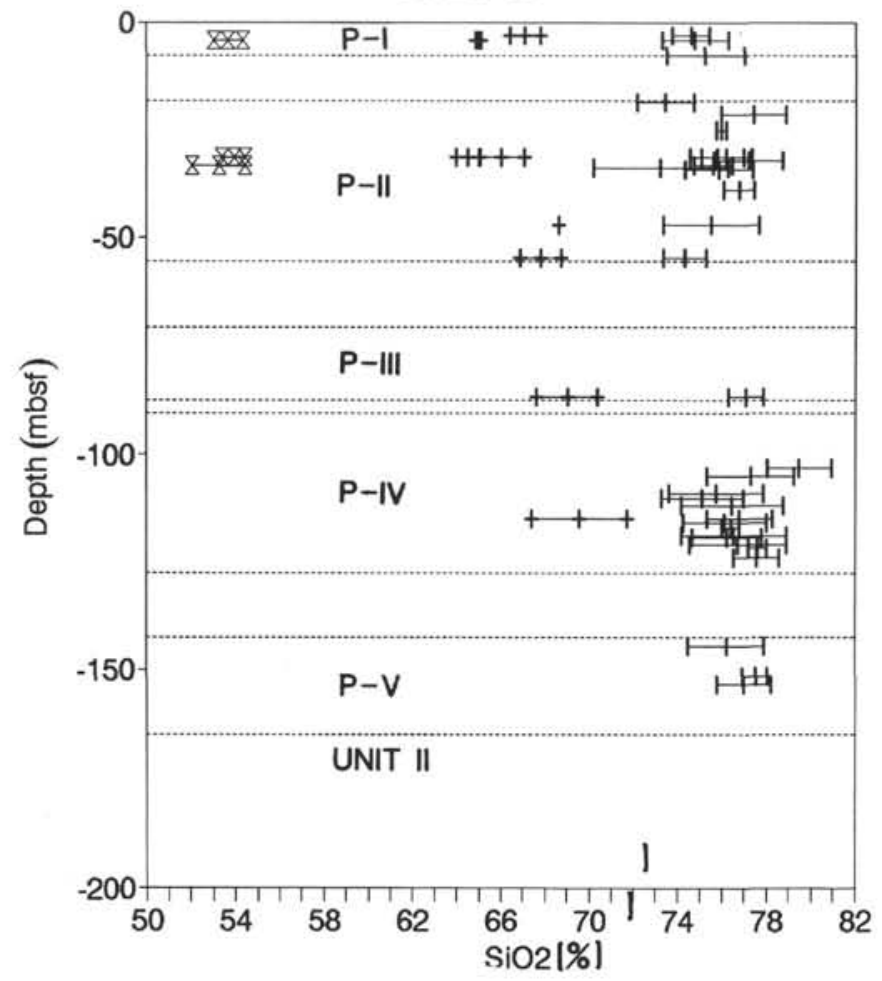

SITE 791

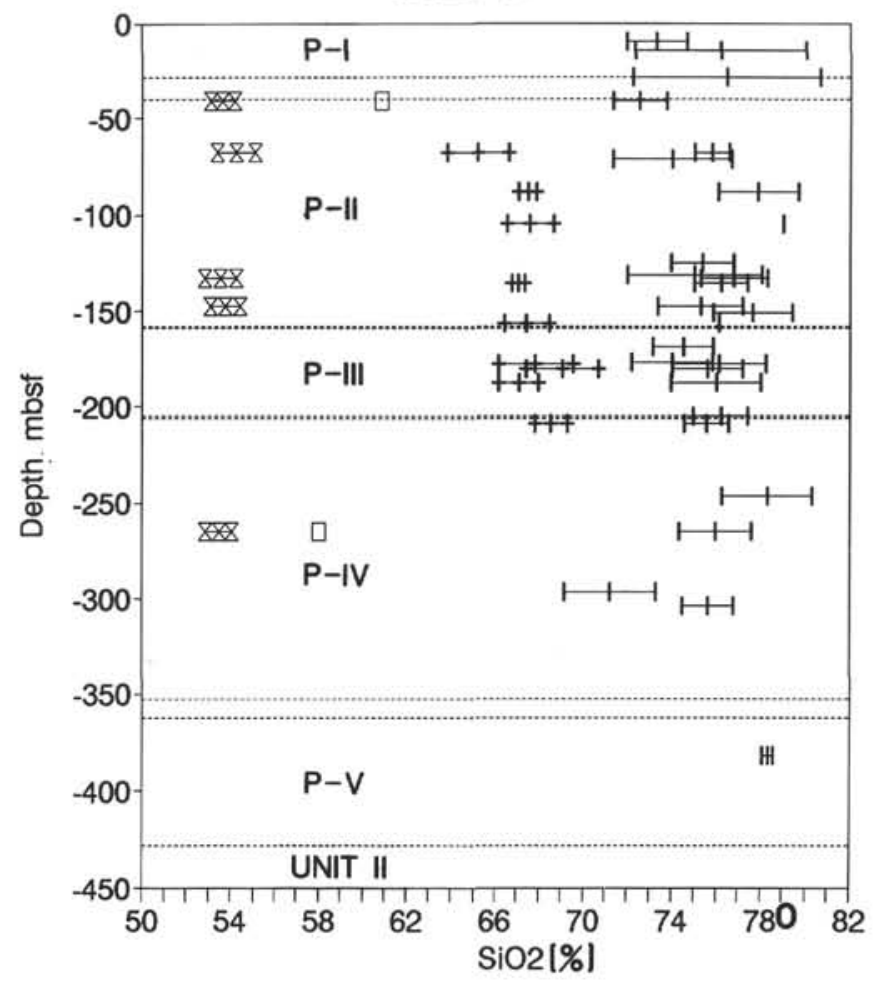

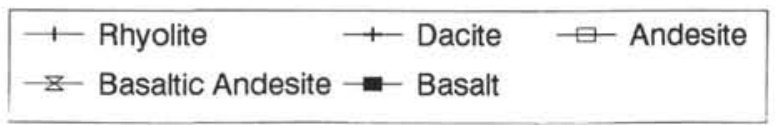

Figure 7. $\mathrm{SiO}_{2}$ vs. depth for the thick pumice layers of basin Sites 790 and 791 . Each line represents \pm 1 standard deviation (SD) from the indicated average.

addition to more mafic activity, more silicic volcanism can also be significant. Andesitic explosive eruptions also occurred before the Izu-Bonin rifting, but the andesitic component in our samples is relatively minor-typically $5 \%$ or less, except in two layers at Site 788 that contain $41 \%$ and $19 \%$ (at 69.93 mbsf and 191.5 mbsf, respectively). We must caution, however, that explosive silicic volcanism is probably over-represented to an unknown extent in the record of the volcaniclastic sequences we analyzed.

We must also caution that our data do not enable us to tell whether the less abundant shards in a mixed assemblage are juvenile or accidental. If they are accidental, they can tell us little about chronologic changes in arc geochemistry. If all the shards in both geochemically homogeneous and multi-modal ash layers are juvenile, a possible explanation is that the products of minor eruptions tend to be compositionally more uniform than those from larger eruptions (Hildreth, 1981), in which case the homogeneous and mixed layers simply record small and large eruptions, respectively. This explanation still does not negate the possibility that shards may be incorporated accidentally during any eruption, either by explosive entrainment from conduit walls or erosionally during downslope movements of tephra masses.

The minor components in mixed ashes could well be juvenile. Kuno (1962) has documented that the 1952 submarine eruption of Miyojinsho volcano in the Izu-Bonin region produced pumice ranging in composition from dacite to rhyolite. Blake and Ivey (1986) and Spera et al. (1986) have shown that a single eruption may simultaneously tap zoned magmas of more than one composition. Hildreth (1981) has reviewed geochemical data from numerous tuffs produced by caldera eruptions in western North America and elsewhere; he observed that all that exceed a few cubic kilometers in volume, and many much smaller ones are compositionally heterogeneous and commonly exhibit wide compositional gaps. He thinks that mantlederived basalts fundamentally govern the evolution of nearly all magmatic systems. It supplies heat and mass, and generates diapirism, which causes complex feedbacks between crustal melting and interception of basaltic intrusions that generate and amplify magma anomalies and suppress basaltic volcanism. He also mentioned the importance of chemical transport by volatiles degassed during basalt crystallization, and states that the typical heterogeneity in a magma chamber is enhanced by assimilation of partial melts, as well as fractionation, which generates zonation.

All the pre- and syn-rift rhyolites and andesites belong to the low-alkali, island-arc tholeiitic suite and contrast markedly with the alkalic products of Holocene volcanism on the northernmost Mariana arc that Stern et al. (1984) have attributed to nascent rifting. Remarkably, the Pliocene-Pleistocene geochemistry of the volcanic front does not appear to have been influenced by rifting only a few kilometers away. Elsewhere, the results of Gill et al. (1984) indicate that rhyolitic volcanism probably occurred during initial backarc development in the Tonga-Fiji region (although the timing of rifting- 8 to $5.5 \mathrm{Ma}$-is not well constrained), and that syn-rift alkalic volcanism also occurred. The Izu-Bonin data show clearly that rhyolitic volcanism was not initiated during rifting, but predated it as well. This may indicate separate sources for the rhyolites and the syn-rift basalts of Site 791 described by Gill et al. (1990), but this speculation needs to be evaluated with trace-element data.

\section{Geochemical Evolution and Correlation}

One objective of our work was to evaluate possible geochemical differences between the tephra above and below the Pliocene-Qua- 

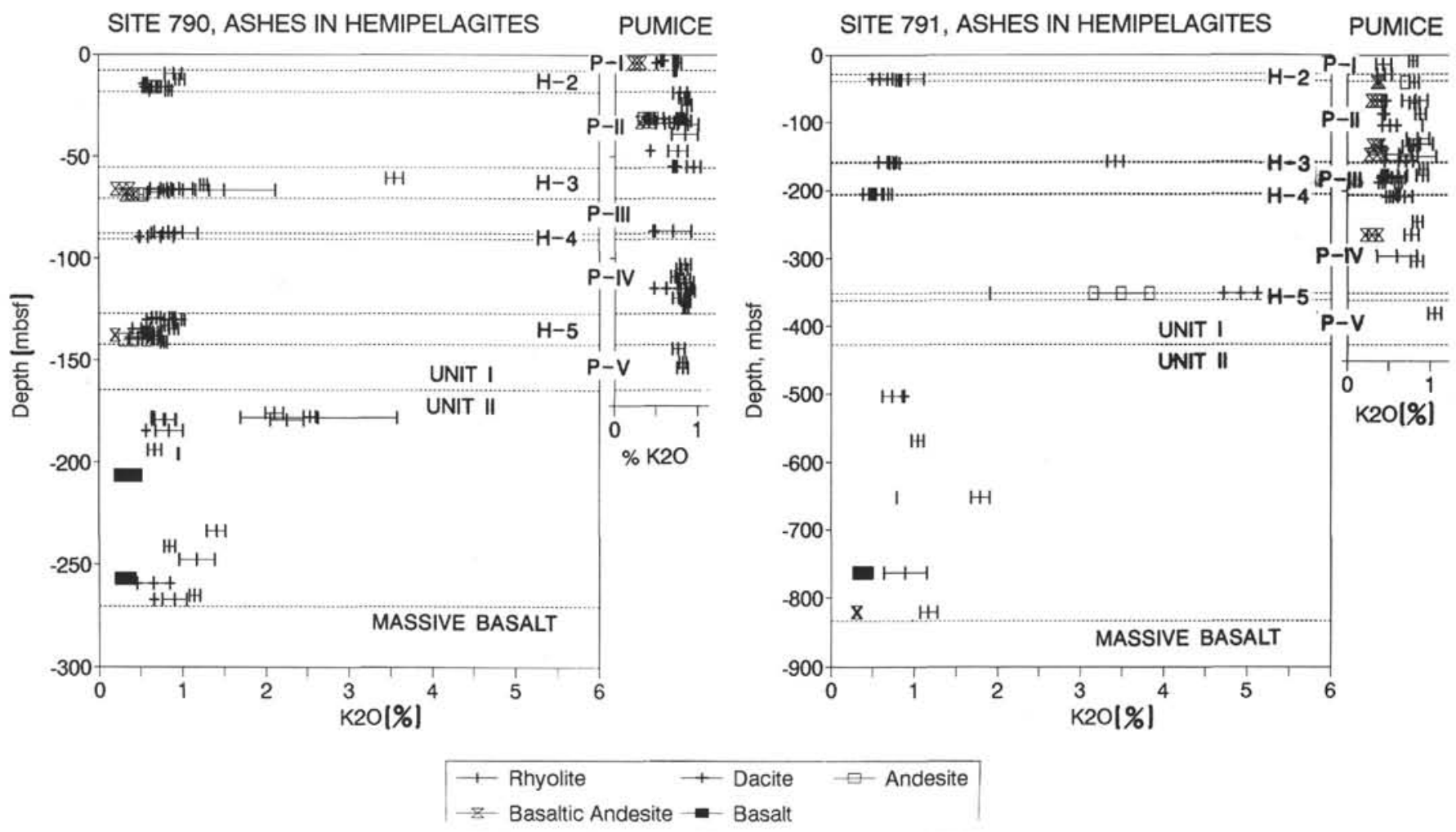

Figure 8. $\mathrm{K}_{2} \mathrm{O}$ vs. depth at Sites 790 and 791. The ranges of $\mathrm{K}_{2} \mathrm{O}$ composition from the thin ash beds in the hemipelagic intervals are plotted separately from those of the thick pumice layers. Each line represents \pm 1 standard deviation (SD) from the indicated average.

ternary hiatus in the rift flank succession at Site 788. We considered this important because any changes across the hiatus should relate directly to the influence of rifting on arc magmatism; however, our results are equivocal. To begin with, the biostratigraphically determined hiatus is not clearly identifiable in the plots of major elements with depth (Fig. 6). Indeed, qualitative perusal of these plots suggest that if the hiatus were accompanied by significant stratigraphic changes in glass-shard chemistry, then the uppermost sample below the unconformity (at $34.44 \mathrm{mbsf}$ ) should instead lie above it. In any case, the Quaternary dacites and andesites are both more potassic than those of Pliocene age. In this intraoceanic setting, the increases in potassium are almost certainly not the result of assimilation of continental crust, or of sediments derived from it. The only viable hypotheses (cf. Gill, 1981) are assimilation from arc crust at upper levels, and variations either in the degree of partial melting of the source magmas, or in metasomatic fluids. Our data cannot address which of these hypotheses may be correct. The Pliocene succession presents another minor enigma: a single basaltic shard from the thin ash at $70 \mathrm{mbsf}$ in Hole $788 \mathrm{C}$ (Sample $788 \mathrm{C}-8 \mathrm{H}-2,73-75 \mathrm{~cm}$ ) is very high in $\mathrm{TiO}_{2}$, and has a $\mathrm{K}_{2} \mathrm{O}$ content intermediate between those of the associated andesite and rhyolite.

If the uppermost three samples (26.31-6.2 mbsf) from Site 788 were derived from a single source, the slight upward increases in titanium, iron, and magnesium of the dacites and rhyolites might indicate tapping of progressively less silicic magma over time. Our results from the Quaternary rift-basin successions corroborate the shipboard finding (Taylor, Fujioka, et al., 1990, p. 121) that the older thick Quaternary pumice layers (P-V and P-IV) are more silicic than the younger ones, a trend that is best shown in the succession of Site 790 (Figs. 7 and 9). The Quaternary rhyolite pumice on the rift flank demonstrates close compositional affinities with Layers P-II and P-IV of the rift-basin, especially with P-IV. Figure 9 illustrates the affinities using silica and titanium; this is true also for iron, calcium, and aluminum. The analysis of Nishimura et al. (this volume) yields ages of 31 and $67 \mathrm{Ka}$ for Layers P-II and P-IV, respectively. Either of these ages would help explain the high degree of shard hydration, and the discoloration and fines-depletion of the Quaternary pumice at Site 788, indicating several tens of thousands of years of exposure at or close to the seafloor.

\section{Provenance}

Most of the rhyolites, in the thick pumice beds and in the thin ash layers, are low-K and therefore most easily ascribed to sources in the arc. However, the thin beds of fine, well-sorted ash within the hemipelagic intervals of the rift-basin successions that contain higher-K suites must have come from other, more distal sources. These anomalous samples include layers in the middle of Unit II at both rift-basin sites; the four layers in the uppermost interval of Unit II at Site 790 (176.2-179.86 mbsf); the single layer analyzed from hemipelagic Interval H-5 at Site 791 (352.81 mbsf); and the occurrences in hemipelagic Interval H-3 (the white ash layer at 60.96 mbsf of Site 790 and the ash layer that contains $30 \%$ medium-K rhyolites at $158.55 \mathrm{mbsf}$, Site 791). The most likely source for these anomalous ashes is Japan. Alkali mapping of the Japanese Quaternary volcanic rocks by Aramaki and $\mathrm{Ui}$ (1983) shows that those of the Izu-Bonin Arc characteristically have low $\mathrm{K}_{2} \mathrm{O}$ values, whereas magmas of southwest Japan Arc (Kyushu) contain distinctly more $\mathrm{K}_{2} \mathrm{O}$, possibly from crustal contamination.

The basaltic ashes in the layers near the bases of the rift-basin successions at Sites 790 and 791 were not derived from the arc. They deviate strongly from trends that the arc-derived glasses display on oxide-oxide plots (Figs. 10A and 10B). Instead, they show close compositional affinities to the basalts erupted all over the Sumisu Rift during incipient rifting, including the basaltic "mousse" underlying the sedimentary succession at Site 791 (Ikeda and Yuasa, 1989; Fryer et al., 1990; Gill et al., 1990), and the basalts of the en echelon ridge 
SITE 790

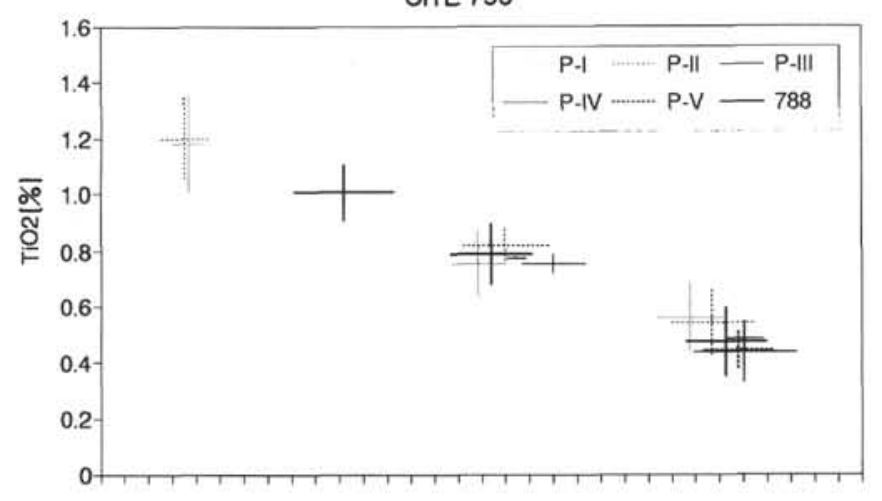

SITE 791

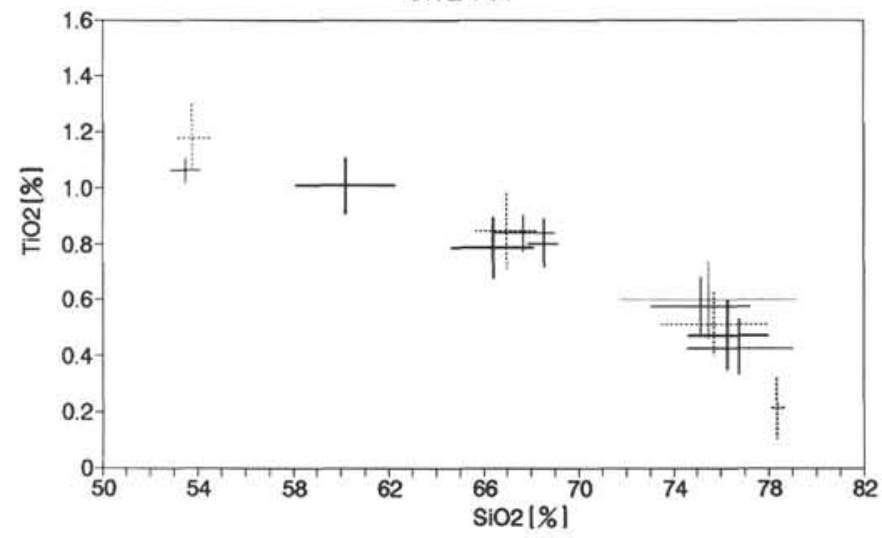

Figure 9. Plots of $\mathrm{SiO}_{2}$ vs. $\mathrm{TiO}_{2}$ for the various rock types in the thick pumice layers of rift-basin Sites 790 and 791. The results from the Quaternary pumice layer of Site 788 are also plotted for comparison. Each cross represents the combined results from each pumice layer, with each arm indicating one standard deviation.

complex that divides the rift into the separate Kita Sumisu and Minami Sumisu basins (Fig. 1), which Hochstaedter et al. (1990) sampled during ALVIN dives (Fig. 10C). The basal basaltic ashes . have an approximate age of $0.75 \mathrm{Ma}$ (Fig. 3), and the basalt from 206 mbsf at Site 790 is about $0.5 \mathrm{Ma}$ in age, and thus are penecontemporaneous with the en echelon ridges determined by $\mathrm{K} / \mathrm{Ar}$ methods (0.05-0.6 Ma). All these basalts and basalt glasses are compositionally similar to those erupted from mature backarc basins elsewhere (Hochstaedter et al., 1990).

\section{ACKNOWLEDGMENTS}

We thank the Leg 126 crew of JOIDES Resolution, especially Captain Anthony Ribbens, and the entire ODP staff of shipboard and shore-based technical and logistics personnel, for helpfulness far "beyond the call." Pre- and post-cruise discussions with J. Gill, K. Marsaglia, and B. Taylor were useful and instructive. We also thank G. Harris at UICDoGS for assisting with analyses, instrument maintenance, and much technical advice. Many thanks are owed to $\mathrm{H}$. Schminke for his review, and for the exceptionally detailed, critical, and instructive comments by our other ODP reviewer, A. Hochstaedter.

\section{REFERENCES}

Aramaki, S., and Ui, T., 1983. Alkali mapping of the Japanese Quaternary volcanic rocks. J. Volcanol. Geotherm. Res., 18:549-560.

Bence, A. E., and Albee, A. L., 1968. Empirical correction factors for the electron microanalysis of silicate and oxides. J. Geol., 76:382-403.
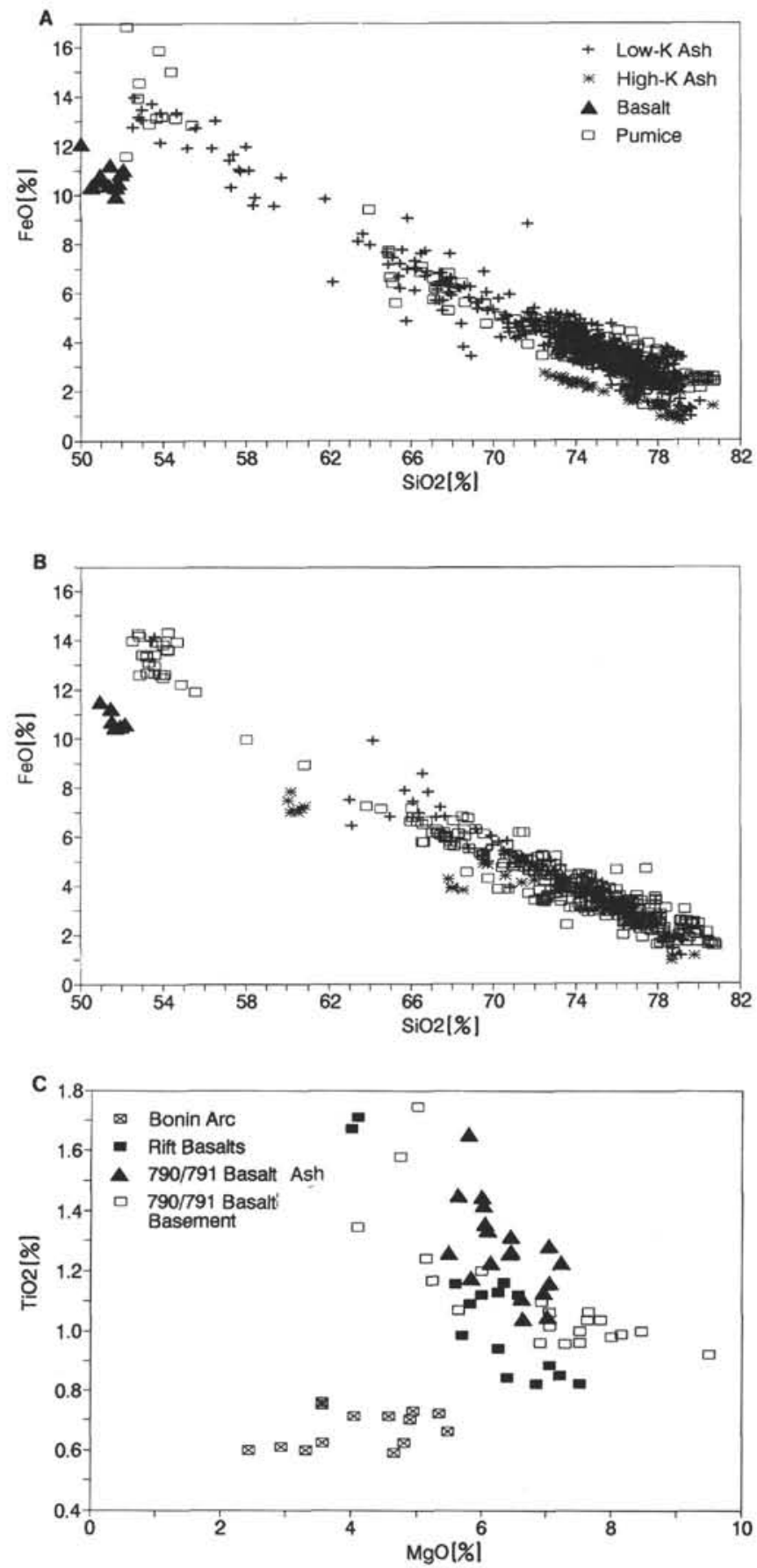

Figure 10. A. $\mathrm{SiO}_{2}-\mathrm{FeO}$ plot of all analyses at Site 790. B. Same, for Site 791. C. $\mathrm{MgO}-\mathrm{TiO}_{2}$ plot for basalts of the Izu-Bonin region, together with individual analysis of the shards from the basaltic ash layers of Sites 790 and 791 (modified from Taylor, Fujioka, et al., 1990, Fig. 63A, p. 190).

Blake, S., and Ivey, G. N., 1986. Magma mixing and the dynamics of withdrawal from stratified reservoirs. J. Volcanol. Geotherm. Res., 27:153-178.

Cadet, J. P., Thisse, Y., Pouclet, A., Bardintzeff, J., and Stephan, J., 1982. Tephra from Deep Sea Drilling Project Leg 66: Middle American Trench Transect. In Watkins, J. S., Moore, J. C., et al., Init. Repts. DSDP, 66: Washington (U.S. Govt. Printing Office), 687-696.

Fryer, P., Taylor, B., Langmuir, C. H., and Hochstaedter, A. G., 1990. Petrology and geochemistry of lavas from the Sumisu and Torishima back-arc rifts. Earth Planet. Sci. Lett., 100:161-178. 
Gill, J., Torssander, P., Lapierre, H., Taylor, R., Kaiho, K., Koyama, M., Kusakabe, M., Aitchison, J., Cisowski, S., Dadey, K., Fujioka, K., Klaus, A., Lovell, M., Marsaglia, K., Pezard, P., Taylor, B., and Tazaki, K., 1990. Explosive deep water basalt in the Sumisu backarc rift. Science, 248:1214-1217.

Gill, J. B., 1981. Orogenic Andesites and Plate Tectonics: New York (Springer-Verlag).

Gill, J. B., Stork, A. L., and Whelan, P. M., 1984. Volcanism accompanying backarc basin development in the Southwest Pacific. Tectonophysics, 102:207-224.

Hawkins, J. W., Bloomer, S. H., Evans, C. A., and Melchior, J. T., 1984. Evolution of intra-oceanic arc-trench systems. Tectonophysics, 102:175-205.

Hervig, R. L., Dunbar, N., Westrich, H. R., and Kyle, P. R., 1989. Pre-eruptive water content of rhyolitic magmas, as determined by ion microprobe analysis of melt inclusions in phenocrysts. J. Volcanol. Geotherm. Res., 36:93-302.

Hildreth, W., 1981. Gradients in silicic magma chambers: implications for lithospheric magmatism. J. Geophys. Res., 86:10153-10192.

Hochstaedter, A. G., Gill, J. B., Kusakabe, M., Newman, S., Pringle, M. Taylor, B., and Fryer, P., 1990. Volcanism in the Sumisu rift. I. Major element, volatile and stable isotope geochemistry. Earth Planet. Sci. Lett., 100:179-194.

Ikeda, Y., and Yuasu, M., 1989. Volcanism in nascent back-arc basins behind the Shichito Ridge and adjacent areas in the Izu-Ogasawara arc, northwest Pacific: evidence for mixing between E-type MORB and island arc magmas and the initiation of backarc rifting. Contrib. Mineral. Petrol. 101:377-393.

Jones, E.J.W., 1973. Volcanic glass in abyssal clays sampled at DSDP Leg 20 drilling sites, northwest Pacific. In Heezen, B. C., MacGregor, I. D., et al., Init. Repts. DSDP, 20: Washington (U.S. Govt. Printing Office), $389-402$.

Kobayashi, K., 1984. Subsidence of the Shikoku back-arc basin. Tectonophysics, 102:105-117.

Kuno, H., 1962. Catalogue of the Active Volcanoes of the World, Part II: Japan, Taiwan, and Marianas. Int. Assembly Volc. Chem. Earth's Interior.
Ninkovitch, D., 1979. Distribution, age and chemical composition of tephra layers in deep-sea sediments off western Indonesia. J. Volcanol. Geotherm. Res., 5:67-86.

Nishimura, A., Marsaglia, K. M., Rodolfo, K. S., Collela, A., Hiscott, R. N., Tazaki, K., Gill, J. B., Janecek, T., Firth, J., Isminger-Kelso, M., Herman, Y., Taylor, R. N., Taylor, B., Fujioka, K., and Leg 126 Scientific party, 1991. Pliocene-Quaternary submarine pumice deposits in the Sumisu rift area, Izu-Bonin arc. In Fisher, R. V., and Smith, G. A. (Eds.), Sedimentation in Volcanic Settings. Spec. Publ.-Soc. Econ. Paleontol. Mineral., 45:201-208.

Peccerillo, A., and Taylor, S. R., 1976. Geochemistry of Eocene calc-alkaline volcanic rocks from the Kastamonu area, northern Turkey. Contrib. Mineral. Petrol., 58:63-81.

Pouclet, A., Cadet, J.-P., Fujioka, K., and Bourgois, J., 1985. Ash layers from Deep Sea Drilling Project Leg 84: Middle America Trench transect. In von Huene, R., Aubouin, J., et al., Init. Repts. DSDP, 84: Washington (U.S. Govt. Printing Office), 609-618.

Pouclet, A., Fujioka, K., Charnet, J., and Cadet, J. P., 1986. Petrography and geochemistry of volcanic ash layers from Leg 87A. Nankai Trough (South Japan). In Kagami, H., Karig, D. E., et al., Init. Repts. DSDP, 87: Washington (U.S. Govt. Printing Office), 695-700.

Scheidegger, K. F., Jezek, P. A., and Ninkovitch, D., 1978. Chemical and optical studies of glass shards in Pleistocene and Pliocene ash layers from DSDP Site 192, northwest Pacific Ocean. J. Volcanol. Geotherm. Res., 4:99-116.

Spera, F. J., Yuen, D. A., Greer, J. C., and Sewell, G., 1986. Dynamics of magma withdrawal from stratified magma chambers. Geology, 14:723-726.

Stern, R., Smoot, N., and Rubin, M., 1984. Unzipping of the Volcano Arc, Japan. Tectonophysics, 102:153-174.

Taylor, B., Fujioka, K., et al., 1990. Proc. ODP, Init. Repts., 126: College Station, TX (Ocean Drilling Program).

Date of initial receipt: 1 January 1991

Date of acceptance: 6 September 1991

Ms 126B-152 